Review

\title{
Preclinical and Clinical Sex Differences in Antipsychotic-Induced Metabolic Disturbances: A Narrative Review of Adiposity and Glucose Metabolism
}

\author{
Laura N. Castellani ${ }^{1}$, Kenya A. Costa-Dookhan ${ }^{1,2}$, William B. McIntyre ${ }^{1}$, \\ David C. Wright ${ }^{3}$, Stephanie A. Flowers ${ }^{4}$, Margaret K. Hahn ${ }^{1,2,5,6, *}$, \\ Kristen M. Ward ${ }^{7}$ \\ 1 Centre for Addition and Mental Health, Toronto, ON M5T1L8, Canada \\ 2 Institute of Medical Science, Faculty of Medicine, University of Toronto, \\ Toronto, ON M5S3K1, Canada \\ 3 Human Health and Nutritional Sciences, University of Guelph, Guelph, ON \\ N1G1Y2, Canada \\ 4 Department of Pharmacy Practice, University of Illinois, Chicago, IL 60607, USA \\ 5 Department of Psychiatry, University of Toronto, Toronto, ON M5T1R8, Canada \\ 6 Banting and Best Diabetes Centre, University of Toronto, ON M5G2C4, Canada \\ 7 Department of Clinical Pharmacy, University of Michigan College of Pharmacy, \\ Ann Arbor, MI 48109, USA \\ * Correspondence: Margaret K. Hahn, Email: Margaret.hahn@camh.ca.
}

\begin{abstract}
Antipsychotic (AP) medications are associated with an increased risk of developing metabolic side effects including weight gain, type 2 diabetes (T2D), dyslipidemia, and hypertension. In the majority of clinical studies, females on APs are noted to gain more weight, and are more likely to be diagnosed with metabolic syndrome when compared to males. However, the data is less clear when comparing sex disparities associated with other specific AP-induced metabolic risk factors. Accumulating evidence has demonstrated a role for AP-induced adipose tissue accumulation as well as whole body glucose dysregulation in male models that is independent of changes in body weight. The purpose of this narrative review is to explore the susceptibility of males and females to changes in adiposity and glucose metabolism across clinical and preclinical models of AP treatment. It is important that future research examining AP-induced metabolic side effects analyzes outcomes by sex to help clarify risk and identify the mechanisms of adverse event development to improve safe prescribing of medications.
\end{abstract}

Copyright $@ 2019$ by the author(s). Licensee Hapres, London, United Kingdom. This is KEYWORDS: visceral adipose tissue; insulin resistance; metabolic side effects; sex differences; antipsychotics an open access article distributed under the terms and conditions of Creative Commons Attribution $\underline{4.0 \text { International License. }}$ 


\section{INTRODUCTION}

Antipsychotics (APs), particularly so called "second" (SGA), and now "third" generation agents, are pivotal in the treatment of schizophrenia and bipolar disorder. They are also being used at increasing rates in patients with depression [1], off-label for conditions such as sleep disorders [2], and for behavioral regulation in children and adolescents [3,4].

The rising prevalence of AP use is concerning for the severe metabolic side effects associated with these drugs. It is well established that AP medications contribute to high rates of metabolic co-morbidity in patients with severe mental illness, in addition to the pre-existing intrinsic metabolic risk attributable to psychiatric illness. For example, in patients with first episode schizophrenia, significant weight gain of at least $7 \%$ baseline body weight has been reported to occur in up to $86 \%$ of patients taking the SGA olanzapine within the first year of treatment [5]. Moreover, the use of APs has been independently associated with the development of Type 2 diabetes (T2D) [6]. When looking at patients with schizophrenia without age restrictions, the rate of T2D is an astounding 3-5 times higher than that of the general population [7]. Rates of glucose intolerance have been reported to exceed $~ 55 \%$ in young patients with schizophrenia spectrum disorders on APs [8]. Moreover, the incidence of T2D is higher in AP-treated youth compared to untreated individuals with a psychiatric diagnosis as noted by a cumulative odds of T2D diagnosis of 2.09 (95\% CI 1.50-52.90; $P<0.0001)$, suggesting that the metabolic risk accrued because of these agents occurs early on in illness [9]. Similarly, in a large cohort of patients in the Danish Psychiatric Central Research Register, patients with schizophrenia who were treated with an AP were at significantly greater risk of developing diabetes when compared to AP-naïve patients with schizophrenia, even after adjusting for confounders (hazard ratio 3.06; 95\% CI 1.32-7.05) [10]. Healthy individuals treated in the short term with a standard dose of APs also show similar susceptibility to disturbances in glucose metabolism [11,12].

The goal of this review is to summarize preclinical and clinical literature that has compared sex differences in select adiposity measures and glucose metabolism. We will describe rates of total weight gain, measures of adiposity, and glucose metabolism by sex, while highlighting proposed mechanisms for all disparities.

\section{METHODS}

To identify relevant literature, PubMed was searched using metabolic adverse drug event terms paired with generic drug names or medication classes. Example searches included "drug name AND sex OR gender AND weight gain”, “APs AND adiposity”, "APs AND metabolic syndrome” and "insulin resistance AND APs". Given the abundance of work exploring AP-induced glucose dysregulation, weight gain, and changes in adiposity we chose to focus on the influence of sex on these outcomes. Although 
lipid metabolism was not a focus of this review a brief search was conducted using the search terms "APs AND lipid metabolism" and "sex differences AND lipid metabolism”. Research exploring AP-induced dyslipidemia with respect to sex differences was limited. Moreover, rodents do not appear to be a good model for AP-induced dyslipidemia, with most available studies failing to find effects of subchronic olanzapine treatment on the lipid profile of rodents [13-16], at odds with what is observed clinically. As such, the topic of dyslipidemia was not included as a focus of the current review.

The use of the search term "gender" was included to capture literature that may have inappropriately classified sex differences as gender differences. Citation lists from critical studies were also reviewed for additional references. Resulting literature is presented below as preclinical (animal studies) or clinical (observational or prospective human subjects studies).

\section{RESULTS}

\section{Sex Differences and Total Body Weight Gain Associated with AP Exposure}

\section{Clinical Data}

A large body of clinical research has associated female sex with an increased risk of weight gain due to APs [17-25] (Table 1A). Some of these studies have enrolled patients on either clozapine or olanzapine, the two APs known to be associated with the highest rates of weight gain. More recently, Lau et al. retrospectively compared weight gain among 110 patients (average age of 34.5) with schizophrenia taking clozapine [17]. They identified female sex as a risk factor for significant weight gain when measured at 3 to 12 months into therapy. There was a $+5.5 \%$ body weight increase in females vs a $+1.3 \%$ body weight increase in males, $P=0.01$ ) [17]. These results are in agreement with a study from 2004 that compared weight gain among patients randomized to open-label clozapine $v s$ continuation with a first generation AP (FGA) [18]. Patients on clozapine gained more weight than patients maintained on a FGA over a 2-year period, and the weight gain was significantly higher in women. Data retrospectively analyzed from 3826 patients involved in olanzapine clinical trials also identified female sex among other risk factors (e.g., younger age, and lower baseline body mass index [BMI]) for increased weight gain associated with olanzapine use [24]. 
Table 1. Clinical study highlights examining weight gain and adiposity changes associated with antipsychotics in patients with serious mental illness.

\begin{tabular}{|c|c|c|c|}
\hline \multicolumn{4}{|c|}{ A. Weight Gain Associated with Antipsychotics } \\
\hline AUTHORS & PARTICIPANTS & AP TREATMENT & METABOLIC OUTCOME \\
\hline $\begin{array}{l}\text { Lau et al. } \\
\text { (2016) [17] }\end{array}$ & $\begin{array}{l}\text { - } \text { Retrospective Study } \\
\text { - Males }(n=67)+ \\
\text { Females }(n=50) \\
\text { - } \text { Mean age: } 34.5\end{array}$ & $\begin{array}{l}\text { Clozapine use for at least } \\
1 \text { year (Compared } 3 \text { month } \\
\text { to } 12 \text { month treatment time } \\
\text { points) } \\
\text { - Average clozapine dose of } \\
\sim 300 \mathrm{mg} \text { (3 months) and } \\
\sim 316 \mathrm{mg} \text { (12 months) }\end{array}$ & $\begin{array}{l}\text { Females gained significantly } \\
\text { more body weight during } 9 \\
\text { month clozapine treatment } \\
\text { (5.5\% weight increase in } \\
\text { females } v s 1.2 \% \text { increase in } \\
\text { males) }\end{array}$ \\
\hline $\begin{array}{l}\text { Covell et al. } \\
\text { (2004) [18] }\end{array}$ & $\begin{array}{l}\text { - Patients with } \\
\text { schizophrenia } \\
\text { - Non-responsive to } \\
\text { treatment with } 2 \text { other } \\
\text { APs } \\
\text { - Males }(n=43)+ \\
\text { females }(n=60)\end{array}$ & $\begin{array}{l}\text { - Switched to clozapine and } \\
\text { monitored for } 2 \text { year } \\
\text { treatment } \\
\text { - Control patients remained } \\
\text { on “usual care” }\end{array}$ & $\begin{array}{l}\text { - Significantly more women } \\
\text { (28\%) become obese } \\
\text { compared to men (3\%) } \\
\text { treated with clozapine } \\
\text { - Significantly more women } \\
\text { (29\%) gained more than } 20 \% \\
\text { baseline weight compared to } \\
\text { men (13\%) over } 2 \text { year } \\
\text { clozapine treatment period }\end{array}$ \\
\hline $\begin{array}{l}\text { Xiang et al. } \\
\text { (2011) [19] }\end{array}$ & $\begin{array}{l}\text { - } \text { Retrospective survey } \\
\text { - Inpatients with } \\
\text { schizophrenia } \\
\text { - Males (3734) + females } \\
\text { (2707) } \\
\text { - Mean age: } 44.0 \\
\end{array}$ & - 3 months of AP treatment & $\begin{array}{l}\text { - Significantly more female } \\
\text { patients recorded complaints } \\
\text { of weight gain compared to } \\
\text { males }\end{array}$ \\
\hline $\begin{array}{l}\text { Hakko et al. } \\
\text { (2006) [21] }\end{array}$ & $\begin{array}{l}\text { - Longitudinal study } \\
\text { - } \text { Males + females } \\
\text { - } \text { Age: Birth-31 years } \\
\text { - } \text { Males (2947) + } \\
\text { Females (3026) }\end{array}$ & $\begin{array}{l}\text { - BMI measured at } 14 \text { and } 31 \\
\text { years of age } \\
\text { - Lifestyle and health } \\
\text { questionnaire administered at } \\
31 \text { years of age to assess } \\
\text { variables that included } \\
\text { medication use and diagnoses, } \\
\text { but ultimately there was not } \\
\text { enough data to include } \\
\text { antipsychotic use information } \\
\text { in model }\end{array}$ & $\begin{array}{l}\text { Females with a psychiatric } \\
\text { disorder were significantly } \\
\text { more likely than men to } \\
\text { transition from under or } \\
\text { normal weight to overweight } \\
\text { or obese (3.6 fold risk females } \\
\text { vs } 2.1 \text { fold risk in males) }\end{array}$ \\
\hline
\end{tabular}


Table 1. Cont.

\begin{tabular}{|c|c|c|c|}
\hline \multicolumn{4}{|c|}{ A. Weight Gain Associated with Antipsychotics } \\
\hline AUTHORS & PARTICIPANTS & AP TREATMENT & METABOLIC OUTCOME \\
\hline $\begin{array}{l}\text { Verma et al. } \\
\text { (2009) [22] }\end{array}$ & $\begin{array}{l}\text { - } \text { Prospective and } \\
\text { naturalistic study } \\
\text { - First-episode psychiatric } \\
\text { disorders with no prior } \\
\text { AP exposure } \\
\text { - } \text { Males }(n=29)+ \\
\text { females }(n=27) \\
\text { - } \text { Mean age: } 29.8 \\
\end{array}$ & $\begin{array}{l}\text { - } 6 \text { month AP treatment } \\
\text { - } \quad \text { Included mono and dual } \\
\text { therapy (60.7\% received an } \\
\text { FGA, } 62.5 \% \text { received an SGA) }\end{array}$ & $\begin{array}{l}\text { - BMI was significantly } \\
\text { increased following } 6 \text { month } \\
\text { treatment } \\
\text { - Female sex was a significant } \\
\text { predictor of weight gain }\end{array}$ \\
\hline $\begin{array}{l}\text { Lee } \text { et al. } \\
\text { (2004) [23] }\end{array}$ & $\begin{array}{l}\text { - In-patients diagnosed } \\
\text { with schizophrenia } \\
\text { - Males }(n=24)+ \\
\text { females }(n=48) \\
\text { - Mean age } \\
\text { (olanzapine): } 33.9 \\
\text { - Mean age } \\
\text { (risperidone): } 36.3\end{array}$ & $\begin{array}{l}\text { - Olanzapine treatment average } \\
103.5 \text { weeks, average dose } \\
12.4 \mathrm{mg} / \text { day } \\
\text { - Risperidone treatment, } \\
\text { average } 93.2 \text { weeks, average } \\
\text { dose } 4.5 \mathrm{mg} / \text { day }\end{array}$ & $\begin{array}{l}\text { - Olanzapine and risperidone } \\
\text { treatment resulted in weight } \\
\text { gain } \\
\text { - No effect of gender on weight } \\
\text { gain risk }\end{array}$ \\
\hline $\begin{array}{l}\text { Lipkovich et } \\
\text { al. (2009) [24] }\end{array}$ & $\begin{array}{l}\text { - Patients diagnosed } \\
\text { with schizophrenia, } \\
\text { schizophrenia } \\
\text { spectrum disorders, } \\
\text { bipolar mania, bipolar } \\
\text { depression, or } \\
\text { borderline personality } \\
\text { disorder ( } n=3826) \\
\text { - Mean age: } 38.8 \\
\end{array}$ & 30 week olanzapine treatment & $\begin{array}{l}\text { - Female sex was significantly } \\
\text { associated with probability of } \\
\text { severe weight gain }\end{array}$ \\
\hline $\begin{array}{l}\text { Attux et al. } \\
\text { (2007) [25] }\end{array}$ & $\begin{array}{l}\text { - First episode psychotic } \\
\text { outpatients } \\
\text { - Males }(n=26)+ \\
\text { females }(n=18) \\
\text { - Mean age:26.3 } \\
\text { - (females significantly } \\
\text { older than males; } \\
\text { mean age } 32.8 \text { vs } 21.9 \text { ) }\end{array}$ & 6 month antipsychotic treatment & $\begin{array}{l}\text { - Both males and females } \\
\text { exhibited increased BMI and } \\
\text { weight gain } \\
\text { - Only females showed } \\
\text { increased waist circumference }\end{array}$ \\
\hline $\begin{array}{l}\text { Taylor et al. } \\
\text { (2018) [26] }\end{array}$ & $\begin{array}{l}\text { - Youths with } \\
\text { schizophrenia or } \\
\text { schizoaffective } \\
\text { disorder } \\
\text { - Males }(n=47)+ \\
\text { females }(n=22) \\
\text { - Mean age: } 14.15\end{array}$ & $\begin{array}{l}8 \text { weeks of antipsychotic } \\
\text { treatment with molindone, } \\
\text { risperidone, or olanzapine }\end{array}$ & $\begin{array}{l}\text { Sex did not predict or moderate } \\
\text { weight change or percent weight } \\
\text { change }\end{array}$ \\
\hline
\end{tabular}


Table 1. Cont.

\begin{tabular}{|c|c|c|c|}
\hline \multicolumn{4}{|c|}{ A. Weight Gain Associated with Antipsychotics } \\
\hline AUTHORS & PARTICIPANTS & AP TREATMENT & METABOLIC OUTCOME \\
\hline $\begin{array}{l}\text { Susilova et } \\
\text { al. (2017) [27] }\end{array}$ & $\begin{array}{l}\text { - } \text { Retrospective study } \\
\text { - Inpatients with a } \\
\text { diagnosis of } \\
\text { schizophrenia or } \\
\text { schizoaffective } \\
\text { disorder } \\
\text { - Males ( } n=466)+ \\
\text { females ( } n=271 \text { ) } \\
\text { - Mean age: } 30 \text { (males), } \\
38.3 \text { (females) }\end{array}$ & $\begin{array}{l}\text { - Average length of hospital } \\
\text { stay range } 29.4 \text { days-41.8 days } \\
\text { - Received AP monotherapy } \\
\text { and polytherapy }\end{array}$ & $\begin{array}{l}\text { - Greater increase in BMI and } \\
\text { weight gain in response to } \\
\text { polytherapy in men but not } \\
\text { women } \\
\text { - No significant difference in } \\
\text { weight changes between males } \\
\text { and females in response to } \\
\text { some atypical APs } \\
\text { - Significant increase in BMI in } \\
\text { men but not women in } \\
\text { response to multi-receptor APs } \\
\text { and aripiprazole }\end{array}$ \\
\hline $\begin{array}{l}\text { Lane } \text { et al. } \\
\text { (2006) [28] }\end{array}$ & $\begin{array}{l}\text { - AP naïve patients with } \\
\text { schizophrenia } \\
\text { - Male }(n=68)+\text { female } \\
(n=55) \\
\text { - Mean age: } 34.0\end{array}$ & $\begin{array}{l}\text { - } 42 \text { day risperidone } \\
\text { monotherapy }\end{array}$ & $\begin{array}{l}\text { Male patients gained more } \\
\text { weight than females (by an } \\
\text { average of } 0.650 \mathrm{~kg} \text { ) }\end{array}$ \\
\hline \multicolumn{4}{|c|}{ B. Adiposity Changes Associated with Antipsychotics } \\
\hline AUTHORS & PARTICIPANTS & $\begin{array}{l}\text { AP TREATMENT AND } \\
\text { ADIPOSITY MEASUREMENT } \\
\text { APPROACH }\end{array}$ & METABOLIC OUTCOME \\
\hline $\begin{array}{l}\text { Konarzewska } \\
\text { et al. } \\
\text { (2014) [29] }\end{array}$ & $\begin{array}{l}\text { - Normal weight } \\
\text { patients diagnosed } \\
\text { with schizophrenia } \\
\text { and BMI-matched } \\
\text { controls } \\
\text { - Patients with } \\
\text { schizophrenia: males } \\
(n=33)+\text { females } \\
(n=19) \\
\text { - Healthy controls: } \\
\text { males (23) + females } \\
\text { (22) } \\
\text { - Mean age: } 42.13\end{array}$ & $\begin{array}{l}\text { - At least } 3 \text { months of } \\
\text { continuous treatment with an } \\
\text { AP prior to beginning the } \\
\text { study, and total use of at least } \\
1 \text { year, for patients with } \\
\text { schizophrenia } \\
\text { - BIA }\end{array}$ & $\begin{array}{l}\text { - Males and females with } \\
\text { schizophrenia had significantly } \\
\text { increased visceral adipose } \\
\text { tissue mass compared to } \\
\text { healthy controls } \\
\text { - Men with schizophrenia had } \\
\text { significantly greater visceral } \\
\text { adipose tissue compared to } \\
\text { females with schizophrenia } \\
\text { ( 5-fold) }\end{array}$ \\
\hline
\end{tabular}


Table 1. Cont.

\begin{tabular}{|c|c|c|c|}
\hline \multicolumn{4}{|c|}{ B. Adiposity Changes Associated with Antipsychotics } \\
\hline AUTHORS & PARTICIPANTS & AP TREATMENT & METABOLIC OUTCOME \\
\hline $\begin{array}{l}\text { Sugawara } \\
\text { et al. (2012) } \\
{[30]}\end{array}$ & $\begin{array}{l}\text { - Outpatients diagnosed } \\
\text { with schizophrenia } \\
\text { - } \text { Males }(n=74)+ \\
\text { females }(n=130) \\
\text { - } \text { Mean age: } 41.3\end{array}$ & $\begin{array}{l}\text { - AP use was defined by } \\
\text { chlorpromazine equivalents, } \\
\text { but type and duration of AP } \\
\text { was not defined } \\
\text { - BIA }\end{array}$ & $\begin{array}{l}\text { - BMI was increased in males } \\
\text { and females with } \\
\text { schizophrenia compared to } \\
\text { healthy controls } \\
\text { - } \text { Females with schizophrenia } \\
\text { had greater body weight, body } \\
\text { fat, fat- free mass, muscle } \\
\text { mass, and body water } \\
\text { compared to healthy females } \\
\text { - Males with schizophrenia body } \\
\text { fat, and \% body fat were } \\
\text { significantly higher (while lean } \\
\text { mass, and body water content } \\
\text { were higher in health males) }\end{array}$ \\
\hline $\begin{array}{l}\text { Zhang et al. } \\
\text { (2004) [31] }\end{array}$ & $\begin{array}{l}\text { - } \text { AP-naïve patients with } \\
\text { schizophrenia } \\
\text { - } \text { Male }(n=27)+\text { women } \\
(n=19) \\
\text { - } \text { Mean age: } 26.9\end{array}$ & $\begin{array}{l}\text { - } 10 \text { week AP treatment } \\
\text { - MRI }\end{array}$ & $\begin{array}{l}\text { - } 10 \text { week treatment with } \\
\text { risperidone, chlorpromazine, } \\
\text { or quetiapine increased } \\
\text { visceral and SQ fat in males } \\
\text { - Adipose tissue gain was } \\
\text { attenuated in females } \\
\text { compared to males }\end{array}$ \\
\hline $\begin{array}{l}\text { Satoh et al. } \\
\text { (2007) [32] }\end{array}$ & $\begin{array}{l}\text { - } \text { Males with } \\
\text { schizophrenia } \\
\text { - } n=80 \text { (+64 healthy } \\
\text { controls) }\end{array}$ & $\begin{array}{l}\text { - All patients with } \\
\text { schizophrenia were on an AP } \\
\text { (duration not defined) } \\
\text { - BIA }\end{array}$ & $\begin{array}{l}\text { - Significantly increased body } \\
\text { fat and lower intracellular } \\
\text { fluid in men with } \\
\text { schizophrenia } \\
\text { - Total body fluid decreased in } \\
\text { men with schizophrenia }\end{array}$ \\
\hline
\end{tabular}

AP: antipsychotic, BIA: bioelectrical impedance analysis, MRI: magnetic resonance imaging.

In contrast, several studies have found no association between female sex and increased risk of weight gain, or even higher rates of weight gain in men following AP exposure (Table 1A). In a recent study among 119 patients between the ages of 8-19 years of age with schizophrenia or schizoaffective disorder, sex was not found to be a predictor or moderator of weight change over 8 weeks of receiving an SGA [26]. In 2017 Susilova et al. observed that men were more likely to gain weight than women when comparing 462 patients (average age of 30 in males and 38.3 in females) with schizophrenia or schizoaffective disorder in the Czech Republic [27]. Similar results were identified in a study of 123 Han Chinese patients with schizophrenia (average age of 34) treated for up to 42 days with risperidone [28]. There is significant heterogeneity in trials with respect to several factors including study population, duration of 
current treatment, specific agent used, and past medication exposure that may explain the conflicting results.

\section{Preclinical data (AP-induced changes in body weight)}

In contrast to clinical findings, preclinical work in rodent models has shown more consistent sex-specific differences in the weight gain response to AP exposure. Specifically, repeated treatment with olanzapine has been consistently shown to increase body weight in female [33-46], but not male [33,43,47-55] rats compared to vehicle treated animals. Indeed, in female rats changes in body weight are apparent within approximately 1 week of olanzapine treatment [34,40,46], with some changes reported as early as 24 to $48 \mathrm{~h}$ after the initial dose, and coinciding with increases in food intake [33].

Female models

\section{Olanzapine treatment in female rats}

Considerable work has been conducted exploring the effects of route and dose of olanzapine administration on adverse metabolic effects. Repeated olanzapine dosing (i.e., 7 days to 13 months) has been shown to increase body weight in female rats across numerous modes of dosing and routes of administration (Table 2A). Olanzapine administered via subcutaneous minipumps for 14 and 30 days has been shown to increase body weight in female rats at doses ranging from $4 \mathrm{mg} / \mathrm{kg} / \mathrm{day}$ to 8 $\mathrm{mg} / \mathrm{kg} /$ day [41,42]. Many studies have similarly shown a potent effect of orally administered olanzapine, both via oral gavage and mixed in with food, in increasing body weight at doses and durations spanning 1.2 $\mathrm{mg} / \mathrm{kg} /$ day to $20 \mathrm{mg} / \mathrm{kg} / \mathrm{day}$ for 10 to 20 days respectively [33,34,43,45,56]. These effects are consistent with reports demonstrating increased body weight in female rats in response to treatment with intramuscular depot administration of olanzapine with exposure periods of 25 to 35 days [37,44,46,57]. Intraperitoneal olanzapine administration has been shown to induce significant body weight gain as well [35,38,39].

Interestingly, a sensitization effect was noted by Albaugh et al. 2006, who reported that body weight plateaus after 7 days of oral olanzapine treatment $(4 \mathrm{mg} / \mathrm{kg})$ in female rats [33]. This effect was overcome when olanzapine was increased weekly to a final dose of $20 \mathrm{mg} / \mathrm{kg}$ for 20 days of treatment.

While olanzapine has been shown to increase body weight across a wide range of dosing, it is worth noting that an acute dose of approximately 1-2 $\mathrm{mg} / \mathrm{kg}$ body weight, or a chronic infusion of approximately $7.5 \mathrm{mg} / \mathrm{kg}$ body weight in rodents is thought to represent clinically relevant dosing, in that approximately $60 \%-70 \%$ of dopamine receptors are occupied at this concentration [58]. 
Table 2. Chronic preclinical studies examining antipsychotic effects on weight, adiposity and glucose metabolism.

\begin{tabular}{|c|c|c|c|}
\hline \multicolumn{4}{|c|}{ A. Female Models } \\
\hline STUDY & MODEL & AP DOSE & $\begin{array}{l}\text { EFFECT OF WEIGHT GAIN, FOOD } \\
\text { INTAKE, ADIPOSITY METABOLISM }\end{array}$ \\
\hline $\begin{array}{l}\text { Albaugh } \\
\text { et al. (2006) } \\
\text { [33] }\end{array}$ & $\begin{array}{l}\text { - Female } \\
\text { C57Bl/6J and } \\
\text { A/J mice } \\
\text { - Female Wistar } \\
\text { and Sprague- } \\
\text { Dawley rats }\end{array}$ & $\begin{array}{l}\text { - } \text { Olanzapine (mice); oral; ramped } \\
\text { dosing 4-8 mg/kg; } 10 \text { days } \\
\text { - } \text { Olanzapine (rats); oral; } \\
4 \text { mg/kg-20 mg/kg; } 20 \text { days } \\
\text { - Clozapine (rats); oral; } \\
4 \text { mg/kg-8 mg/kg; } 12 \text { days } \\
\text { - Clozapine + olanzapine (rats); } \\
\text { oral; } 4 \text { mg/kg clz- } 8 \text { mg/kg clz + } \\
4 \text { mg/kg ola } \\
27 \text { days }\end{array}$ & $\begin{array}{l}\text { (Olanzapine } 10 \text { days mice): } \\
\text { - No significant change in body } \\
\text { weight (trend for weight loss, and } \\
\text { decreased food intake) } \\
\text { (Olanzapine } 20 \text { days rats): } \\
\text { - Increased body weight (plateau at 7- } \\
10 \text { days without ramped dosing) } \\
\text { - Increased food intake (starting after } \\
24 \mathrm{~h} \text { ) } \\
\text { - Increased fasting insulin levels (not } \\
\text { fasting glucose) } \\
\text { - No effect on glucose tolerance, } \\
\text { increased insulin during OGTT } \\
\text { (Clozapine- rats): No effect on body } \\
\text { weight, food intake } \\
\text { (Clozapine +Olanzapine-rats): } \\
\text { Increased weight gain, increased } \\
\text { food intake }\end{array}$ \\
\hline $\begin{array}{l}\text { Arjona et al. } \\
\text { (2004) [34] }\end{array}$ & $\begin{array}{l}\text { Female Sprague- } \\
\text { Dawley rats }\end{array}$ & $\begin{array}{l}\text { - Olanzapine; oral gavage; } \\
1.2 \mathrm{mg} / \mathrm{kg} / \text { day; } 10 \text { days } \\
\text { - Haloperidol; oral gavage; } \\
0.04 \mathrm{mg} / \mathrm{kg} / \text { day; } 10 \text { days }\end{array}$ & $\begin{array}{l}\text { - Olanzapine: Significant increase in } \\
\text { body weight and food intake } \\
\text { - Decreased total motor activity } \\
\text { - Haloperidol: No effect on body } \\
\text { weight or food intake }\end{array}$ \\
\hline $\begin{array}{l}\text { Coccurello } \\
\text { et al. (2009) } \\
{[59]}\end{array}$ & $\begin{array}{l}\text { Female } \quad \text { CD-1 } \\
\text { mice }\end{array}$ & $\begin{array}{l}\text { Olanzapine; } 30 \text { day mini-osmotic } \\
\text { pump infusion; } 4 \mathrm{mg} / \mathrm{kg}, 8 \mathrm{mg} / \mathrm{kg}\end{array}$ & $\begin{array}{l}\text { Weight gain, hyperphagia, } \\
\text { hyperglycemia, hyperinsulinemia, } \\
\text { - Increased pancreatic insulin, } \\
\text { increased insulin resistance, i.e., } \\
\text { increased HOMA-IR } \\
\text { - Increased periuterine adipose tissue } \\
\text { - Decreased RER, decreased metabolic } \\
\text { rate }\end{array}$ \\
\hline $\begin{array}{l}\text { Cooper et al. } \\
\text { (2005) [35] }\end{array}$ & $\begin{array}{ll}\text { Female Han } \\
\text { Wistar rats }\end{array}$ & $\begin{array}{l}\text { Olanzapine; I.P.; } 1,2,4 \mathrm{mg} / \mathrm{kg} / \text { day; } \\
\text { Twice daily, } 20 \text { days }\end{array}$ & $\begin{array}{l}\text { - Increased body weight at } 1 \text { and } \\
2 \mathrm{mg} / \mathrm{kg} \text { (not } 4 \mathrm{mg} / \mathrm{kg} \text { ) } \\
\text { - } \text { Increased total food intake ( } 1 \mathrm{mg} / \mathrm{kg} \text { ) } \\
\text { - } \text { Increased perirenal fat pad mass ( } 2 \\
\text { and } 4 \mathrm{mg} / \mathrm{kg} \text { ) } \\
\text { - } \text { No change in fasting glucose levels } \\
\text { - Increased fasting insulin, HOMA-IR } \\
\text { (1 mg/kg) }\end{array}$ \\
\hline
\end{tabular}


Table 2. Cont.

\begin{tabular}{|c|c|c|c|}
\hline \multicolumn{4}{|c|}{ A. Female Models } \\
\hline STUDY & MODEL & AP DOSE & $\begin{array}{l}\text { EFFECT OF WEIGHT GAIN, FOOD } \\
\text { INTAKE, ADIPOSITY METABOLISM }\end{array}$ \\
\hline $\begin{array}{l}\text { Cooper et al. } \\
\text { (2008) [36] }\end{array}$ & $\begin{array}{l}\text { Female Wistar } \\
\text { rats }\end{array}$ & $\begin{array}{l}\text { - Clozapine I.P.; } 1,2,4 \mathrm{mg} / \mathrm{kg} / \mathrm{day} \\
\text { Twice daily } 20 \text { days } \\
\text { - Clozapine; I.P.; } 0.25-0.5 \mathrm{mg} / \mathrm{kg}\end{array}$ & $\begin{array}{l}\text { - Weight loss } \\
\text { - No change in food intake, muscle } \\
\text { mass, levels of glucose, insulin } \\
\text { - Increased visceral adiposity }\end{array}$ \\
\hline $\begin{array}{l}\text { Ersland et al. } \\
\text { (2015) [57] }\end{array}$ & $\begin{array}{l}\text { Female Sprague } \\
\text { Dawley rats }\end{array}$ & $\begin{array}{ll}\text { - } & \text { Olanzapine; intramuscular } \\
\text { injection; } 100 \mathrm{mg} / \mathrm{kg} \text {; Once } \\
\text { - } & \text { Risperidone; intramuscular } \\
\text { injection; } 30 \mathrm{mg} / \mathrm{kg} \text {; Once } \\
\text { - } \quad \text { Olanzapine; intramuscular; } \\
10 \mathrm{mg} / \mathrm{kg} ; 3 \text { doses; } 35 \text { days } \\
\text { - } \quad \text { Risperidone; intramuscular; } \\
15 \mathrm{mg} / \mathrm{kg} ; 3 \text { doses; } 35 \text { days } \\
\end{array}$ & $\begin{array}{l}\text { - Single treatment: Increased food } \\
\text { intake and weight gain } \\
\text { - Repeated dosing: Increased food } \\
\text { intake and weight gain }\end{array}$ \\
\hline $\begin{array}{l}\text { Ersland et al. } \\
\text { (2019) [37] }\end{array}$ & $\begin{array}{l}\text { Female Sprague } \\
\text { Dawley rats }\end{array}$ & $\begin{array}{l}\text { Olanzapine; intramuscular; } \\
100 \mathrm{mg} / \mathrm{kg} ; 13 \text { months }\end{array}$ & $\begin{array}{l}\text { Increased body weight gain; Glucose } \\
\text { intolerance, insulin intolerance }\end{array}$ \\
\hline $\begin{array}{l}\text { Fell et al. } \\
\text { (2004) [38] }\end{array}$ & $\begin{array}{l}\text { Female hooded- } \\
\text { Lister rats }\end{array}$ & $\begin{array}{l}\text { Olanzapine; I.P.; } 0.5-4 \mathrm{mg} / \mathrm{kg} \\
21 \text { days }\end{array}$ & $\begin{array}{l}\text { - Increased body weight and food } \\
\text { intake } \\
\text { - Increased intra-abdominal fat } \\
\text { - No effect on wet/dry uterine weights }\end{array}$ \\
\hline $\begin{array}{l}\text { Ferno et al. } \\
\text { (2011) [51] }\end{array}$ & $\begin{array}{l}\text { Female Sprague- } \\
\text { Dawley rats }\end{array}$ & $\begin{array}{l}\text { Olanzapine; oral gavage; } 3 \mathrm{mg} / \mathrm{kg} \\
\text { Twice daily }\end{array}$ & $\begin{array}{l}\text { - Induced body weight gain } \\
\text { - Increased food intake } \\
\text { - Visual decrease in locomotor activity } \\
\text { - Weight gain was not different from } \\
\text { vehicle in pair-fed animals } \\
\end{array}$ \\
\hline $\begin{array}{l}\text { Goudie et al. } \\
\text { (2002) [39] }\end{array}$ & $\begin{array}{l}\text { Female Wistar } \\
\text { rats }\end{array}$ & $\begin{array}{l}\text { Olanzapine; B.I.D.; } 4 \mathrm{mg} / \mathrm{kg} \\
20 \text { days }\end{array}$ & $\begin{array}{l}\text { - Increased body weight } \\
\text { - No effect of baseline body weight on } \\
\text { weight gain response }\end{array}$ \\
\hline $\begin{array}{l}\text { Hu et al. } \\
\text { (2014) [40] }\end{array}$ & $\begin{array}{l}\text { Female Sprague- } \\
\text { Dawley rats }\end{array}$ & $\begin{array}{l}\text { Olanzapine; } 4 \mathrm{mg} / \mathrm{kg} 7 \text { days + } \\
8 \mathrm{mg} / \mathrm{kg} ; 7 \text { days }\end{array}$ & $\begin{array}{l}\text { - Increased weight gain, adiposity and } \\
\text { food intake compared to vehicle } \\
\text { treated rats } \\
\text { - Olanzapine decreased BAT weight }\end{array}$ \\
\hline $\begin{array}{l}\text { Lykkegaard } \\
\text { et al. (2008) } \\
\text { [41] }\end{array}$ & $\begin{array}{l}\text { Female Sprague- } \\
\text { Dawley rats }\end{array}$ & $\begin{array}{l}\text { Olanzapine; S.C. mini pumps; } \\
1.75 \mathrm{mg} / 24 \mathrm{~h} ; 28 \text { days }\end{array}$ & $\begin{array}{l}\text { - Increased food intake, body weight, } \\
\text { adiposity } \\
\text { - Impaired glucose tolerance (OGTT) }\end{array}$ \\
\hline $\begin{array}{l}\text { Mann et al. } \\
\text { (2013) [42] }\end{array}$ & $\begin{array}{l}\text { Famale Sprague- } \\
\text { Dawley rats }\end{array}$ & $\begin{array}{l}\text { Olanzapine; osmotic minipump, } \\
\text { S.C., i.p.; } 7.5 \mathrm{mg} / \mathrm{kg} / \text { day } \\
14 \text { days }\end{array}$ & $\begin{array}{l}\text { - Increase in body weight } \\
\text { - increased food intake } \\
\text { - Increased adiposity } \\
\end{array}$ \\
\hline
\end{tabular}


Table 2. Cont.

\begin{tabular}{|c|c|c|c|}
\hline \multicolumn{4}{|c|}{ A. Female Models } \\
\hline STUDY & MODEL & AP DOSE & $\begin{array}{l}\text { EFFECT OF WEIGHT GAIN, FOOD } \\
\text { INTAKE, ADIPOSITY METABOLISM }\end{array}$ \\
\hline $\begin{array}{l}\text { Pouzet et al. } \\
\text { (2003) [43] }\end{array}$ & $\begin{array}{l}\text { Female } \\
\text { Mol:Wistar } \\
\text { Hannover rats }\end{array}$ & $\begin{array}{l}\text { - Haloperidol; oral gavage; } 0.08 \\
\text { and } 0.31 \mathrm{mg} / \mathrm{kg} / \text { day } \\
\text { - Olanzapine; oral; } 5.0 \text { and } \\
20 \mathrm{mg} / \mathrm{kg} / \text { day; } 21 \text { days }\end{array}$ & $\begin{array}{l}\text { - Haloperidol and olanzapine } \\
\text { ( } 5 \mathrm{mg} / \mathrm{kg} \text { ) increased body weight } \\
\text { - Olanzapine ( } 20 \mathrm{mg} / \mathrm{kg} \text { ) only } \\
\text { significantly increased body weight } \\
\text { at } 2 \text { weeks; } \\
\text { - Olanzapine }(5 \mathrm{mg} / \mathrm{kg} \text { ) increased } \\
\text { cumulative food intake } \\
\text { - All treatments decreased water } \\
\text { intake }\end{array}$ \\
\hline $\begin{array}{l}\text { Skrede } \text { et al. } \\
\text { (2012) [45] }\end{array}$ & $\begin{array}{l}\text { Female Sprague- } \\
\text { Dawley rats }\end{array}$ & $\begin{array}{l}\text { - Olanzapine; oral gavage; } 6 \mathrm{mg} / \mathrm{kg} \\
\text { - Aripiprazole; oral gavage; } \\
6 \mathrm{mg} / \mathrm{kg} \\
13 \text { days }\end{array}$ & $\begin{array}{l}\text { - Olanzapine increased food intake } \\
\text { and weight gain } \\
\text { - No effect on fasting glucose or } \\
\text { insulin } \\
\text { - Olanzapine increased adipose tissue } \\
\text { mass }\end{array}$ \\
\hline $\begin{array}{l}\text { Skrede } \text { et al. } \\
\text { (2014) [44] }\end{array}$ & $\begin{array}{l}\text { Female Sprague- } \\
\text { Dawley rats }\end{array}$ & $\begin{array}{l}\text { - Olanzapine; depot injection; } \\
112 \mathrm{mg} / \mathrm{kg} \text {; Once, Day } 0 \\
\text { - Second injection } 100 \mathrm{mg} / \mathrm{kg} \\
\text { Once, day } 17 \\
25 \text { day total exposure }\end{array}$ & $\begin{array}{l}\text { - Increased food intake, increased } \\
\text { body weight } \\
\text { - Decreased hypothalamic AMPKa1 at } \\
\text { day } 8\end{array}$ \\
\hline $\begin{array}{l}\text { Skrede } \text { et al. } \\
\text { (2017) [46] }\end{array}$ & $\begin{array}{l}\text { - Female } \\
\text { Sprague } \\
\text { Dawley rats } \\
\text { - Female OVX } \\
\text { Sprague } \\
\text { Dawley rats }\end{array}$ & $\begin{array}{l}\text { Olanzapine; intramuscular; } \\
100 \text { mg/kg; Once; } 8 \text { days }\end{array}$ & $\begin{array}{l}\text { - Increased food intake and body } \\
\text { weight in WT rats } \\
\text { - In OVX olanzapine did not } \\
\text { potentiate increases in food intake, } \\
\text { decreased body weight gain }\end{array}$ \\
\hline
\end{tabular}


Table 2. Cont.

\begin{tabular}{|c|c|c|c|}
\hline \multicolumn{4}{|c|}{ B. Male Models } \\
\hline STUDY & MODEL & AP DOSE & $\begin{array}{l}\text { EFFECT OF WEIGHT GAIN, FOOD } \\
\text { INTAKE, ADIPOSITY METABOLISM }\end{array}$ \\
\hline $\begin{array}{l}\text { Ader et al. } \\
\text { (2005) [47] }\end{array}$ & Male Dogs & $\begin{array}{l}\text { - Olanzapine, oral; } 15 \mathrm{mg} / \text { day } \\
\text { - } \text { Risperidone; oral; } 5 \mathrm{mg} / \text { day } \\
21 \text { days }\end{array}$ & $\begin{array}{l}\text { - Olanzapine decreased fasting } \\
\text { glucose and insulin compared to } \\
\text { baseline } \\
\text { - No significant body weight gain or } \\
\text { food intake compared to placebo } \\
\text { (olanzapine and risperidone) } \\
\text { - Olanzapine significantly increased } \\
\text { adiposity and decreased insulin } \\
\text { sensitivity/ decreased hepatic } \\
\text { insulin sensitivity } \\
\text { - Beta-cell insulin secretion/function } \\
\text { failed during graded hyperglycemic } \\
\text { test (olanzapine) }\end{array}$ \\
\hline $\begin{array}{l}\text { Albaugh } \\
\text { et al. (2006) } \\
{[33]}\end{array}$ & $\begin{array}{l}\text { Male Wistar and } \\
\text { Sprague-Dawley } \\
\text { rats }\end{array}$ & $\begin{array}{l}\text { Olanzapine; oral; } 4-8 \mathrm{mg} / \mathrm{kg} \\
14 \text { days }\end{array}$ & $\begin{array}{l}\text { - No change in body weight or food } \\
\text { intake }\end{array}$ \\
\hline $\begin{array}{l}\text { Albaugh } \\
\text { et al. (2011) } \\
{[48]}\end{array}$ & $\begin{array}{l}\text { Male, } \\
\text { SpragueDawley } \\
\text { rats }\end{array}$ & $\begin{array}{l}\text { Olanzapine; oral in food; ramped } \\
\text { dosing } 4 \mathrm{mg} / \mathrm{kg}-20 \mathrm{mg} / \mathrm{kg} \\
20 \text { days }\end{array}$ & $\begin{array}{l}\text { - Increased fat mass } \\
\text { - Did no effect on body weight or food } \\
\text { intake } \\
\text { - Increased fasting glucose } \\
\text { - Decreased glucose and insulin } \\
\text { tolerance }\end{array}$ \\
\hline $\begin{array}{l}\text { Baptista } \\
\text { et al. (1993) } \\
\text { [49] }\end{array}$ & Male rats & $\begin{array}{l}\text { - Olanzapine; mini-pumps; } \\
5 \mathrm{mg} / \mathrm{kg} / \text { day } \\
\text { - Clozapine; mini pumps; } \\
10 \mathrm{mg} / \mathrm{kg} / \text { day } \\
11 \text { days }\end{array}$ & $\begin{array}{l}\text { No effect on food intake or body } \\
\text { weight in male rats }\end{array}$ \\
\hline $\begin{array}{l}\text { Cooper et al. } \\
\text { (2007) [50] }\end{array}$ & $\begin{array}{l}\text { Male Han Wistar } \\
\text { rats }\end{array}$ & $\begin{array}{l}\text { Olanzapine; I.P.; } 1,2,4 \mathrm{mg} / \mathrm{kg} / \text { day } \\
\text { Twice daily } 20 \text { days }\end{array}$ & $\begin{array}{l}\text { - Decreased body weight and no effect } \\
\text { on food intake } \\
\text { - Enhanced visceral adiposity and } \\
\text { reduced lean muscle mass } \\
\text { - No increase in plasma levels of } \\
\text { insulin or glucose, decreased } \\
\text { testosterone levels }\end{array}$ \\
\hline
\end{tabular}


Table 2. Cont.

\begin{tabular}{|c|c|c|c|}
\hline \multicolumn{4}{|c|}{ B. Male Models } \\
\hline STUDY & MODEL & AP DOSE & $\begin{array}{l}\text { EFFECT OF WEIGHT GAIN, FOOD } \\
\text { INTAKE, ADIPOSITY METABOLISM }\end{array}$ \\
\hline $\begin{array}{l}\text { Ferno et al. } \\
\text { (2015) [51] }\end{array}$ & $\begin{array}{l}\text { Male Sprague } \\
\text { Dawley rats }\end{array}$ & $\begin{array}{l}\text { - Olanzapine; depot injection; } \\
100 \mathrm{mg} / \mathrm{kg} \\
\text { Once } \\
\text { - Second injection } 100 \mathrm{mg} / \mathrm{kg} \\
\text { Once, day } 9 \\
17 \text { day total exposure }\end{array}$ & $\begin{array}{l}\text { - Transient hyperphagia ( 7 days) } \\
\text { - Weight loss } \\
\text { - Increased mesenteric WAT and liver } \\
\text { weight } \\
\text { - Decreased body weight compared to } \\
\text { vehicle treated HFD-fed rats } \\
\text { - Worsened adiposity compared to } \\
\text { HFD fed rats }\end{array}$ \\
\hline $\begin{array}{l}\text { Houseknecht } \\
\text { et al. (2007) } \\
{[60]}\end{array}$ & $\begin{array}{l}\text { Male Wistar Han } \\
\text { rats }\end{array}$ & $\begin{array}{l}\text { Clozapine; S.C.; } 10 \mathrm{mg} / \mathrm{kg} \text {; } \\
5 \text { days }\end{array}$ & $\begin{array}{l}\text { - Increased insulin resistance (HIEC } \\
\text { with 5th dose) } \\
\text { - Changes in body weight not reported }\end{array}$ \\
\hline $\begin{array}{l}\text { Minet- } \\
\text { Ringuet et al. } \\
\text { (2006) [52] }\end{array}$ & $\begin{array}{l}\text { Male Sprague- } \\
\text { Dawley rats }\end{array}$ & $\begin{array}{l}\text { - Olanzapine; oral with food; } 0.01 \text {, } \\
\text { 0.1, 0.5, } 2 \mathrm{mg} / \mathrm{kg} ; 6 \text { weeks } \\
\text { - Haloperidol; oral with food; } \\
1 \mathrm{mg} / \mathrm{kg} ; 3 \text { weeks } \\
\text { - } \text { Olanzapine; oral with food, } \\
1 \mathrm{mg} / \mathrm{kg} ; 3 \text { weeks } \\
\text { - } \text { Ziprasidone; oral with food; } \\
10 \mathrm{mg} / \mathrm{kg} ; 3 \text { weeks }\end{array}$ & $\begin{array}{l}\text { - Olanzapine ( } 6 \text { weeks): } 0.5 \mathrm{mg} / \mathrm{kg} \text {, } \\
2 \mathrm{mg} / \mathrm{kg} \text { increased body weight } \\
\text { - } \text { Matched by increase in } \\
\text { subcutaneous adipose tissue } \\
\text { - Olanzapine ( } 3 \text { weeks) but not } \\
\text { haloperidol or ziprasidone } \\
\text { increased body weight and energy } \\
\text { intake }\end{array}$ \\
\hline $\begin{array}{l}\text { Minet- } \\
\text { Ringuet et al. } \\
\text { (2006) [53] }\end{array}$ & $\begin{array}{l}\text { Male Sprague-- } \\
\text { Dawley rats }\end{array}$ & $\begin{array}{l}\text { - Haloperidol; oral in food; } 1 \mathrm{mg} / \mathrm{kg} \\
\text { - Olanzapine; oral in food; } \\
1 \mathrm{mg} / \mathrm{kg} \text {. } \\
\text { - Ziprasidone; oral in food; } \\
10 \mathrm{mg} / \mathrm{kg} \\
6 \mathrm{Weeks}\end{array}$ & $\begin{array}{l}\text { - No effect of treatment on body } \\
\text { weight } \\
\text { - Haloperidol and olanzapine } \\
\text { increased adiposity (s.c. and } \\
\text { retroperitoneal WAT) } \\
\text { - Haloperidol increased } \\
\text { retroperitoneal BAT } \\
\text { - Olanzapine increased intrascapular } \\
\text { BAT } \\
\text { - No effect on cumulative caloric } \\
\text { intake or food selection }\end{array}$ \\
\hline $\begin{array}{l}\text { Pouzet et al. } \\
\text { (2003) [43] }\end{array}$ & $\begin{array}{l}\text { Male } \\
\text { Mol:Wistar } \\
\text { Hannover rats }\end{array}$ & $\begin{array}{l}\text { - Haloperidol; oral gavage; } \\
0.08 \text { and } 0.31 \mathrm{mg} / \mathrm{kg} / \text { day } \\
\text { - Olanzapine; oral; } 5.0 \text { and } \\
20 \mathrm{mg} / \mathrm{kg} / \text { day } \\
21 \text { days }\end{array}$ & $\begin{array}{l}\text { - Olanzapine }(20 \mathrm{mg} / \mathrm{kg}) \text { decreased } \\
\text { body weight } \\
\text { - All other groups had no effect on } \\
\text { body weight } \\
\text { - No effect of treatments on food } \\
\text { intake }\end{array}$ \\
\hline
\end{tabular}


Table 2. Cont.

\begin{tabular}{|c|c|c|c|}
\hline \multicolumn{4}{|c|}{ B. Male Models } \\
\hline STUDY & MODEL & AP DOSE & $\begin{array}{l}\text { EFFECT OF WEIGHT GAIN, FOOD } \\
\text { INTAKE, ADIPOSITY METABOLISM }\end{array}$ \\
\hline $\begin{array}{l}\text { Smith et al. } \\
\text { (2008) [54] }\end{array}$ & $\begin{array}{l}\text { Male Sprague } \\
\text { dawley rats }\end{array}$ & $\begin{array}{l}\text { - Haloperidol; } 0.25 \mathrm{mg} / \mathrm{kg} \\
\text { - } \text { Quetiapine;10 mg/kg } \\
\text { - Clozapine;10 mg/kg } \\
28 \text { days }\end{array}$ & $\begin{array}{l}\text { - Haloperidol and clozapine } \\
\text { decreased body weight compared to } \\
\text { vehicle treatment, no change in fat } \\
\text { percentage } \\
\text { - Quetiapine showed no difference in } \\
\text { body weight, but } 40 \% \text { increase in fat } \\
\text { pad mass }\end{array}$ \\
\hline $\begin{array}{l}\text { Smith et al. } \\
\text { (2009) [55] }\end{array}$ & $\begin{array}{l}\text { Male Sprague } \\
\text { dawley rats } \\
\text { (chow + HFD) }\end{array}$ & $\begin{array}{l}\text { Clozapine (10 mg/kg), quetiapine } \\
\text { (10 mg/kg) S.C.; } 42 \text { days }\end{array}$ & $\begin{array}{l}\text { - Quetiapine alone increased } \\
\text { adiposity, no additive effect with } \\
\text { HFD } \\
\text { - Clozapine alone decreased adiposity; } \\
\text { no additive effect of HFD } \\
\text { - both quetiapine and clozapine } \\
\text { increased blood glucose levels 1-h } \\
\text { post treatment at } 42 \text { days of } \\
\text { treatment } \\
\text { - worsened glucose tolerance via GTT, } \\
\text { additive to HFD }\end{array}$ \\
\hline
\end{tabular}

AP: antipsychotic, OGTT: oral glucose tolerance test, HIEC: Hyperinsulinemic-euglycemic clamp, WAT: white adipose tissue, BAT: brown adipose tissue, HFD: high fat diet, GTT: glucose tolerance test.

\section{Olanzapine treatment in female mice}

Interestingly, unlike female rats, female mice did not show changes in body weight in response to 10 day olanzapine treatment increasing from $4 \mathrm{mg} /$ day to $8 \mathrm{mg} /$ day (administered orally) [33]. However, female mice treated with olanzapine for 30 days via osmotic mini-pump did respond with increased body weight [59]. Six-week olanzapine treatment mixed into a high fat diet (45\% kcal fat) also increased body weight in female mice allowed ad libitum access to food, however this effect was lost when mice were pair-fed to match food intake of vehicle-fed mice on the high fat diet. Species-specific responses have not been carefully considered but could involve differences in metabolic rate between rats and mice, or differences in hepatic drug clearance. Changes in body composition or metabolic substrates/hormones in response to olanzapine were not assessed in response to the 10-day olanzapine treatment.

\section{Clozapine treatment in female rats}

In contrast to olanzapine, clozapine had no effect on weight gain, or food intake after 10 days of ramped oral administration $(4 \mathrm{mg} / \mathrm{kg}$ to final dose of $8 \mathrm{mg} / \mathrm{kg}$ ) in female rats; however weight gain effects were observed when clozapine was co-administered with olanzapine for an 
additional 14 day period [33]. In agreement with this work, Cooper et al. [36] demonstrated that clozapine alone (administered via intraperitoneal injection) led to decreased body weight in female rats after a 20 day treatment period.

Haloperidol treatment in female rats

Although adverse metabolic effects associated with AP use are often attributed to SGAs, metabolic effects are also observed in response to FGAs. Indeed, female rats also showed susceptibility to haloperidolinduced weight gain, in response to oral gavage treatment for 21 days at doses of $0.08 \mathrm{mg} / \mathrm{kg} /$ day and $0.31 \mathrm{mg} / \mathrm{kg} /$ day [43] but not 10 days at $0.04 \mathrm{mg} / \mathrm{kg} /$ day [34].

Male models

Olanzapine treatment in male rats and dogs

In contrast to preclinical female models, chronic olanzapine treatment (ranging from 7 to 28 days) in male rats has been shown to have no effect on body weight gain [33,48,49,52,53], with some studies reporting decreases in body weight over the treatment period [43,50,51] (Table 2B). This is mirrored by a similar response in male dogs, which did not show changes in body weight or feeding in response to 21-day oral olanzapine treatment [47]. The lack of effect of AP exposure on body weight gain is apparent across treatments, including intramuscular [51] and intraperitoneal [50] injection, oral administration (gavage and mixed in with food) [33,43,48,53] and miniosmotic pumps [49]. Notably, olanzapine-induced increases in body weight are apparent when olanzapine is paired with a "medium-fat diet" (containing 14\% proteins, $31 \%$ lipids, and $54 \%$ carbohydrates) rather than the standard chow diet. In these rats, 3 and 6 week olanzapine treatment resulted in increased body weight and energy intake [52]. This aligns with work by Townsend et al showing high fat diet to independently potentiate acute olanzapineinduced metabolic complications in male mice [61].

\section{Clozapine and haloperidol treatment in male rats}

The lack of effect of olanzapine on weight gain in male rat models was consistent with a lack of effect of other APs. While 28 day treatment with haloperidol $(0.25 \mathrm{mg} / \mathrm{kg} / \mathrm{day})$ or clozapine $(10 \mathrm{mg} / \mathrm{kg} / \mathrm{day})$ both decreased body weight [54], 3 week haloperidol treatment $(1 \mathrm{mg} / \mathrm{kg} /$ day) mixed in with food had no effect on body weight [53]. Similarly, 21-day haloperidol treatment failed to alter body weight in male rats at doses that initiated weight gain in female rats [43]. Unlike olanzapine, which elicited a weight gain response when paired with a medium fat diet in male rats, haloperidol treatment did not alter body weight or energy intake compared to control medium-fat fed animals [52]. 


\section{Sex Differences in Other Adiposity Measures Associated with AP Exposure}

\section{Clinical data}

As a growing body of research has established in human subject studies, adipose tissue distribution is critically important to diabetes and cardiovascular disease risk [62-64]. Visceral adipose tissue (i.e., fat deposited around the visceral organs) is particularly problematic as it is more metabolically active than subcutaneous adipose tissue and allows entry of free fatty acids directly into the liver via the hepatic portal vein, which can lead to insulin resistance [64].

Studies in humans suggest that males, despite typically gaining less weight when taking APs than females, have greater increases in visceral adipose tissue when using APs (Table 1B). For example, Konarzewska et al. measured visceral obesity in 52 normal weight (BMI $<25 \mathrm{~km} / \mathrm{m}^{2}$ ) patients with chronic schizophrenia (average age of 46 [males] and 41 years old [females]) and compared body composition to BMI-matched controls in a cross-sectional study [29]. Inclusion criteria required that participants be on the same AP for the three months preceding the study visit. In this study, the most commonly used APs were olanzapine, then risperidone, followed by haloperidol and clozapine. The team used bioelectrical impedance analysis to calculate body composition. They found that a schizophrenia diagnosis was significantly linked to higher amount of visceral adipose tissue and lower fat-free mass in both sexes. Furthermore, men with schizophrenia averaged at least 5 times, and women with schizophrenia at least 2 times, as much visceral adipose tissue as age-matched controls.

A similar cross-sectional study in Japan compared body composition among patients with schizophrenia to healthy controls [30]. The study team enrolled 204 subjects, with an average age of 39 (males) and 43 (females), and used bioelectrical impedance to assess body composition. Significant baseline differences between the control and schizophrenia groups, by sex, included shorter stature in the schizophrenia groups, greater body weight in the females with schizophrenia, and higher BMI in the male and female schizophrenia groups. The investigators identified higher body fat, higher percentage body fat, lower fat-free mass and muscle mass, and lower body water among males with schizophrenia when compared to controls. In contrast, females with schizophrenia had a significantly lower percent body fat, higher fat-free mass, higher muscle mass, and higher body water than controls. The investigators did not describe the extent and type of AP use among the patients with schizophrenia, but did cite the inclusion of patients taking either first or later generation APs as a potential study limitation.

Zhang et al. also compared body composition changes using MRI in 46 patients with schizophrenia who were exposed to their initial AP for 10 weeks with age and sex matched healthy controls [31]. In this study, the 
average age of participants was 27 years old. Males with schizophrenia had significantly higher visceral and subcutaneous fat distribution after 10 weeks of treatment with either risperidone, chlorpromazine, or quetiapine, when compared to baseline. In females with schizophrenia, there was a significant, but less profound increase in absolute visceral fat distribution than that observed in the males when compared to baseline (i.e., an average increase of $7.8 \mathrm{~cm}^{2}$ in women compared to an average of $25.2 \mathrm{~cm}^{2}$ gained in men). For both males and females, there were no significant differences between the patients with schizophrenia and the controls.

However, most literature to date comparing body composition between patients with schizophrenia to healthy controls has included all males [32], or did not differentiate results by sex [65-67]. In this regard preclinical data is helpful to elucidate a relationship between sex and body composition changes due to APs.

\section{Preclinical data (AP-induced changes in adiposity)}

In contrast to the discrepancies previously discussed between preclinical and clinical data with respect to sex differences in total body weight gain associated with APs, preclinical data have largely paralleled clinical data in supporting an increased risk of visceral adiposity in males (Table 2).

\section{Female models of AP-induced adiposity}

In line with AP-induced weight gain, female rats exposed to chronic olanzapine treatment displayed increased accumulation of visceral adipose tissue depots compared to vehicle treated control animals [40,42,45] (Table 2A). In a 21 day olanzapine treatment (i.p. injections, $4 \mathrm{mg} / \mathrm{kg} /$ day) study, medication use was associated with increased intraabdominal fat deposition [38]. This was confirmed by Cooper et al. who similarly demonstrated that 20 day olanzapine treatment increased perirenal fat pad mass alongside increases in body weight and food intake [35]. Similarly, female mice exposed to olanzapine for 30 days displayed increased peri-uterine white adipose tissue mass in parallel with increased body weight [59].

Remarkably, although 20-day clozapine treatment decreased body weight in female rats, this treatment simultaneously increased visceral adiposity, independent of changes in food intake or loss of lean mass. In this study clozapine treatment was also associated with an increase in serum adiponectin, which the authors propose could increase adipose tissue insulin sensitivity and subsequently increase lipogenesis [36]. This work highlights the metabolic susceptibility that occurs even in the presence of decreased body weight or stable food intake. 
Male models of AP-induced adiposity

The potential for metabolic complications to occur independent of changes in body weight is especially apparent when considering the effects of chronic AP use in preclinical male models of adiposity (Table 2B).

Indeed, despite a lack of effect on total body weight, 3 week haloperidol and olanzapine treatments (mixed in with food) increased subcutaneous and retroperitoneal white adipose tissue in male rats [53]. In line with this study, reports of olanzapine-induced decreases in body weight over a 20 day treatment period were matched by increases in visceral adiposity and reductions in lean body mass [50], accounting, in part, for reductions in body mass. Reports from Ferno et al. echo these findings, showing that despite a transient increase in food intake in the first 7 days of olanzapine treatment, total body weight was reduced in the total 17-day treatment period alongside increased mesenteric white adipose tissue and increased liver weights [51]. Male dogs show similar increases in adiposity in response to 21-day oral olanzapine administration despite body weights remaining stable during the treatment period [47].

Interestingly, 28-day haloperidol and clozapine treatment reduced body weight in male rats, however these drugs were not found to effect adiposity. By comparison, 28-day quetiapine treatment did not alter body weight compared to vehicle rats, but increased adiposity by approximately $40 \%$ (measured via dual-energy X-ray absorptionmetry [DEXA] scanning) [54]. Extended quetiapine treatment (42 day) was similarly found to increase adiposity, which, in contrast to olanzapine treatment, was not worsened when co-administered with a high fat diet [55].

Ultimately, this literature emphasizes a role for body weightindependent metabolic risk in both male and female models following chronic AP exposure that appears to be conserved across dose, agent, route and species. Given the intimate association between adiposity and other comorbid conditions, such as glucose dysregulation and insulin resistance, it is interesting to consider how these complications might also manifest with sex specific considerations.

\section{Sex Differences in Glucose Metabolism}

In addition to AP-induced changes in adiposity and body weight, APs have been shown to influence glucose dysregulation in individuals with schizophrenia, ultimately promoting the development of T2D in youth [9] and adults [10]. As reviewed by Bergman and Ader, the development of T2D in patients with schizophrenia is independently influenced by many environmental, lifestyle, and genetic factors, making it difficult to delineate the extent of the effects of APs on glycemic risk in this population [6]. Few studies in patients with schizophrenia have examined differences between males and females with schizophrenia with respect to measures of glucose 
metabolism. In a cross-sectional review of 287 patients with schizophrenia on APs (average age of 47), males had higher fasting glucose than females after those taking olanzapine and clozapine were excluded [68].

Studies examining short-term AP use (independent of chronic adipose tissue accumulation) in healthy individuals have offered insight into the effects of APs on glucose disturbances, independently of factors related to the illness of schizophrenia and adiposity. While these effects have been considered in mixed male and female participants, acute dosing studies examining changes in glucose metabolism have yet to directly analyze sexspecific effects.

\section{Clinical data}

Acute dosing in healthy male and female participants

There is a mix of data on the effects of APs on glucose metabolism in healthy human participants (Table 3). A single oral dose of olanzapine (10 $\mathrm{mg} /$ day) was shown to increase fasting blood glucose and decrease glucose effectiveness in 15 male and female (80\% male) drug naïve participants, though insulin levels in response to treatment were not reported. There was no significant effect of sex or ethnicity with respect to the outcomes of interest, except in the case of prolactin where the difference in prolactin levels between olanzapine and placebo was significantly higher in women $\left(t_{12}=4.6, P=0.0006\right)$ [11]. In line with this work, three-day olanzapine treatment combining males and females ( 8 males, 7 females) showed worsened glucose tolerance in response to an oral glucose challenge, with no change in serum insulin [12]. In contrast, acute olanzapine treatment has also been shown to have no effect on fasting glucose levels in combination with increases in serum insulin post-treatment [69,70]. A cohort of 13 male and 4 female participants treated with olanzapine (oral, $10 \mathrm{mg} /$ day) for 15 days had no change in fasting blood glucose, but showed increases in serum insulin, c-peptide levels and body weight [70]. Olanzapine treatment did result in an increased insulin response during a hyperglycemic clamp and also was associated with a decreased insulin sensitivity index. However, when BMI was controlled, these olanzapine-induced changes were no longer observed [70]. On the other hand, seven day olanzapine treated was also associated with the development of insulin resistance, despite no change in fasting glucose levels post-treatment [69]. Sowell et al. further indicated no effect of 21-day olanzapine or risperidone treatment on insulin sensitivity, insulin secretion or glucose tolerance as assessed by a mixed-meal tolerance test in a study of 64 participants (77.3\% males) [71]. Although this work suggests a role for insulin secretion in the initial glycemic response to olanzapine, it fails to delineate sex specific contributions to the metabolic response. Future work directly analyzing the effect of sex in mixed male/female study populations is required to fully understand this relationship. 
Table 3. Acute clinical studies examining changes in glucose metabolism in healthy participants in response to antipsychotic treatment.

\begin{tabular}{|c|c|c|c|}
\hline AUTHORS & PARTICIPANTS & AP TREATMENT & EFFECT ON GLUCOSE METABOLISM \\
\hline $\begin{array}{l}\text { Albaugh et al. } \\
\text { (2011) [12] }\end{array}$ & $\begin{array}{l}\text { Male (8) + Female (7) } \\
\text { Mean age: } 26.6\end{array}$ & $\begin{array}{l}\text { Olanzapine; } 10 \mathrm{mg} / \mathrm{kg} \text {; } \\
3 \text { days }\end{array}$ & $\begin{array}{l}\text { - Worsened glucose tolerance (OGTT) } \\
\text { - No change in serum insulin in response to glucose } \\
\text { bolus }\end{array}$ \\
\hline $\begin{array}{l}\text { Hahn et al. (2013) } \\
\text { [11] }\end{array}$ & $\begin{array}{l}\text { Male (12) + Female (3) } \\
\text { Mean age: } 30.13\end{array}$ & $\begin{array}{l}\text { Olanzapine; oral; } 10 \text { mg } \\
\text { Once }\end{array}$ & $\begin{array}{l}\text { - Increased fasting glucose } \\
\text { - Decreased glucose effectiveness }\end{array}$ \\
\hline $\begin{array}{l}\text { Kopf et al. (2012) } \\
\text { [72] }\end{array}$ & $\begin{array}{l}\text { Male (10) } \\
\text { Age: } 24-30 \text { (no mean) }\end{array}$ & $\begin{array}{l}\text { Olanzapine; Oral; } 10 \text { mg } \\
\text { Once }\end{array}$ & $\begin{array}{l}\text { - No effect on insulin sensitivity (euglycemic- } \\
\text { hyperinsulinemic clamp) } \\
\text { - Insulin secretion remained intact (hyperglycemic } \\
\text { clamp, insulin levels, c-peptide levels) }\end{array}$ \\
\hline $\begin{array}{l}\text { Sowell et al. } \\
\text { (2002) [70] }\end{array}$ & $\begin{array}{ll}\text { - } & \text { Olanzapine } \\
\text { - } & \text { Male (13) + Female } \\
& \text { (4); Mean age: } 33.1 \\
\text { - } & \text { Risperidone } \\
\text { - } & \text { Male (13), Female } \\
& \text { (0); Mean age: } 28.0\end{array}$ & $\begin{array}{l}\text { - Olanzapine; oral; } \\
10 \mathrm{mg} / \text { day } \\
\text { - } \text { Risperidone; oral; } \\
4 \mathrm{mg} / \text { day } \\
\text { 15-17 days }\end{array}$ & $\begin{array}{l}\text { - Increase in body weight } \\
\text { - Increase in fasting insulin/c-peptide levels, no change } \\
\text { in fasting blood glucose } \\
\text { - Insulin response/secretion remained intact } \\
\text { (hyperglycemic clamp) } \\
\text { - Slight decrease in insulin sensitivity (insulin sensitivity } \\
\text { index via hyperglycemic clamp) }\end{array}$ \\
\hline $\begin{array}{l}\text { Sowell et al. (2003) } \\
\text { [71] }\end{array}$ & $\begin{array}{l}\text { Males + Females } \\
\text { (Olanzapine } 77.3 \% \\
\text { males; Risperidone } \\
\text { 57.1\% males, placebo } \\
\text { 68.4\% males) } \\
\text { Mean age: } 33.5\end{array}$ & $\begin{array}{l}\text { - Olanzapine; oral; } \\
10 \mathrm{mg} / \text { day } \\
\text { - } \text { Risperidone; oral; } \\
4 \mathrm{mg} / \text { day } \\
\text { 21-23 days }\end{array}$ & $\begin{array}{l}\text { - Increased weight gain with AP treatment } \\
\text { - No change in insulin sensitivity (HIEC) } \\
\text { - No difference in glucose tolerance or insulin secretion } \\
\text { in response to mixed-meal tolerance test }\end{array}$ \\
\hline $\begin{array}{l}\text { Sacher et al. (2008) } \\
\text { [73] }\end{array}$ & $\begin{array}{l}\text { Males (35) } \\
\text { Mean age: } 24.0\end{array}$ & $\begin{array}{l}\text { - Olanzapine; oral; } \\
10 \mathrm{mg} / \text { day } \\
\text { - Ziprasidone; oral; } \\
80 \mathrm{mg} / \text { day } \\
10 \text { days } \\
\end{array}$ & $\begin{array}{l}\text { - Olanzapine increased BMI } \\
\text { - Olanzapine decreased whole body insulin sensitivity } \\
\text { (HIEC- decreased glucose uptake) } \\
\text { - Olanzapine slightly increased serum insulin levels }\end{array}$ \\
\hline $\begin{array}{l}\text { Teff et al. (2013) } \\
\text { [69] }\end{array}$ & $\begin{array}{l}\text { Males }(21)+ \\
\text { Females (9) } \\
\text { Mean age: } 26.1\end{array}$ & $\begin{array}{l}\text { - Olanzapine; oral; } \\
5 \mathrm{mg}, 2 \text { days, } 10 \mathrm{mg} \text {; } \\
7 \text { days } \\
\text { - } \quad \text { Aripriprazole; oral; } \\
5 \mathrm{mg}, 2 \text { days, } 10 \mathrm{mg} \text {; } \\
7 \text { days }\end{array}$ & $\begin{array}{l}\text { - Olanzapine increased fasting insulin compared to } \\
\text { placebo, no change in fasting blood glucose } \\
\text { - Olanzapine increased post-prandial insulin, GLP-1, } \\
\text { glucagon } \\
\text { - Olanzapine increased insulin resistance (HIEC) } \\
\text { - No change in body weight, physical activity level, total } \\
\text { hunger rating }\end{array}$ \\
\hline $\begin{array}{l}\text { Vidarsdottir et al. } \\
\text { (2009) [74] }\end{array}$ & $\begin{array}{l}\text { Males (12) } \\
\text { Mean age: } 25.1\end{array}$ & $\begin{array}{l}\text { - Olanzapine; oral } \\
\text { standard tablets; } \\
10 \mathrm{mg} / \text { day } \\
\text { - } \text { Olanzapine; oral } \\
\text { disintegrating tablets; } \\
10 \mathrm{mg} / \text { day } \\
8 \text { days }\end{array}$ & $\begin{array}{l}\text { - No change in adiposity } \\
\text { - Olanzapine (both formulations) induced insulin } \\
\text { resistance (HOMA-IR) }\end{array}$ \\
\hline $\begin{array}{l}\text { Vidarsdottir et al. } \\
\text { (2010) [75] }\end{array}$ & $\begin{array}{l}\text { Males (14) } \\
\text { Mean age: } 25.7\end{array}$ & $\begin{array}{l}\text { - Olanzapine; oral; } \\
10 \mathrm{mg} / \text { day } \\
\text { - } \text { Haloperidol; oral; } \\
3 \mathrm{mg} / \text { day } \\
8 \text { days } \\
\end{array}$ & $\begin{array}{l}\text { - Olanzapine had no effect on fasting glucose, insulin } \\
\text { - Olanzapine decreased insulin sensitivity (HIEC) } \\
\text { - Decreased insulin-stimulated glucose disposal } \\
\text { - Olanzapine increased blood glucagon, prolactin }\end{array}$ \\
\hline
\end{tabular}

AP: antipsychotic, OGTT: oral glucose tolerance test, HIEC: Hyperinsulinemic-euclycemic clamp. 
Acute dosing in healthy male participants

Work completed in drug-naïve healthy male participants has shown decreased whole-body insulin sensitivity in response to 8-day olanzapine treatment (10 mg, oral) that was associated with reductions in glucose uptake and/or increases in prolactin but not cortisol levels. Despite no change in adiposity, 10 day olanzapine treatment was associated with an increased homeostatic model assessment of insulin resistance (HOMA-IR) and also with decreased insulin sensitivity [74]. In contrast, Vidarsdottir et al, reported that 8 day olanzapine treatment had no effect on fasting glucose or insulin levels while it increased glucagon concentrations and impaired whole body insulin sensitivity [75]. Unlike 10 day olanzapine treatment which has been shown to decrease whole body insulin sensitivity [73], a single dose of olanzapine $(10 \mathrm{mg})$ did not affect insulin sensitivity or secretion in healthy male participants [72].

\section{Preclinical Data (AP Treatment and Glucose Dysregulation)}

The association between adipose tissue accumulation and the development of insulin resistance has been well established in preclinical and clinical models. It is not surprising then that AP exposure (known to increase adiposity) is linked with impaired insulin sensitivity and glucose intolerance [6]. The effects of APs on glucose dysregulation have been studied using both repeated/chronic and single/acute dosing schedules. Chronic administration of APs such as olanzapine allow insight into the longer-term glucose dysregulation that develops alongside changes in adiposity, and captures changes in whole body energy metabolism over time. In contrast, acute studies afford the opportunity to explore the direct effects of APs on glucose homeostasis, independent of changes in confounding variables such as fat mass or loss of lean mass. Combining these approaches affords the best opportunity to identify mechanisms underlying AP-induced glucose dysregulation and development of T2D.

\section{Chronic AP exposure and glucose dysregulation}

\section{Chronic AP-treatment in male models}

The effects of AP exposure are particularly apparent in preclinical models where changes in body composition occur consistently in response to AP administration across dose, duration and route of administration. In line with increased adiposity, chronic AP treatment has been shown to impair glucose tolerance and whole-body insulin sensitivity in male rodents and dogs (Table 2B).

Indeed, despite observing a consistent lack of changes in body weight, repeated AP-treatment has been shown to impair glucose tolerance and whole insulin sensitivity in male dogs, mice and rats. Ader et al. demonstrated that 21 day olanzapine treatment in male dogs elevated fasting blood glucose and insulin, decreased hepatic insulin sensitivity 
and reduced beta-cell glucose stimulated insulin secretion, despite stable food intake and body weight [47]. Similarly, 20-day ramped olanzapine dosing in male rats resulted in impaired insulin and glucose tolerance as well as increased fasting glucose and insulin levels in the presence of stable body weights [48]. Similar to olanzapine treatment, 42-day clozapine or quetiapine treatment in male rats has been shown to reduce glucose tolerance alongside increases in adiposity, which also potentiated glucose intolerance induced via high fat feeding [55]. Clozapine-induced insulin resistance can be observed as early as 5 days after subcutaneous treatment, although changes in body weight were not reported in these animals [60].

\section{Chronic AP-treatment in female models}

Remarkably, oral olanzapine administration via ramped dosing for 20 days did not affect fasting blood glucose levels or glucose tolerance (as measured by an oral glucose tolerance test) in female rats, although glucose bolus dosing caused increased serum insulin levels which are indicative of the early stages of insulin resistance [33] (Table 2A). In a separate study, fasting blood glucose levels were also unchanged in response to 20 day olanzapine treatment via intraperitoneal injection, however; HOMA-IR was elevated in these animals, suggesting the development of insulin resistance [35]. Similarly, 13 day olanzapine administration by oral gavage was not associated with changes in blood glucose or insulin levels despite increased body weight and adiposity [45]. In line with this work, blood glucose and insulin levels after 20 days of clozapine treatment were not significantly different from vehicle treated female rats, despite increased adipose tissue content [36]. In a significantly longer study, chronic olanzapine treatment via intramuscular injection for an exposure period of 13 months was associated with the development of marked glucose and insulin intolerance [37]. Female mice (who displayed increased body weight and adiposity) treated for 30 days with olanzapine via osmotic mini pumps also showed hyperglycemia and hyperinsulinemia, alongside increased HOMA-IR [59] (Table 2A).

In contrast to male rats and dogs, in whom chronic AP-induced glucose dysregulation is apparent, female rats appear less consistently susceptible to glucose intolerance and hyperglycemia despite increased adiposity and body weight at the onset of AP-treatment. Many have reported that APs impair glucose homeostasis directly, independent of changes in body composition [6]. Given the potent effect of chronic AP dosing on increased adiposity, it is difficult to define the role of APs in the dysregulation of glucose metabolism independent of the diabetogenic effects of obesity. Examining the effects of acute AP treatment on glucose dysregulation can provide better insight into these changes. 
Acute AP exposure and glucose dysregulation

To dissect "direct” effects of APs on glucose homeostasis, acute dosing paradigms, which avoid changes in adiposity, can be helpful. Interestingly, despite increased risk in female rats to AP-induced body weight gain and food intake, male rats show susceptibility to glucose dysregulation which could be, in part, mediated by increased adiposity or loss of lean mass [50] (Table 4). However, as will be reviewed, acute AP treatment suggests susceptibility of male rats and mice to direct disturbances in glucose homeostasis independent of changes in body composition. On the other hand, female rodents appear less susceptible to acute-AP mediated disturbances in glucose metabolism, although less work has been conducted examining this phenomenon in female models.

Table 4. Acute preclinical studies examining direct effects of antipsychotics on glucose metabolism.

\begin{tabular}{|c|c|c|c|}
\hline \multicolumn{4}{|c|}{ A. Female Models } \\
\hline STUDY & MODEL & AP DOSE & EFFECT ON GLUCOSE METABOLISM \\
\hline $\begin{array}{l}\text { Albaugh } \\
\text { et al. (2006) } \\
\text { [33] }\end{array}$ & $\begin{array}{l}\text { Female } \\
\text { Sprague- } \\
\text { Dawley rats }\end{array}$ & $\begin{array}{l}\text { Olanzapine; oral gavage } \\
4 \mathrm{mg} / \mathrm{kg} \\
4 \text { doses over } 29 \mathrm{~h}\end{array}$ & $\begin{array}{l}\text { - Basal fasting glucose was significantly decreased } \\
\text { by olanzapine } \\
\text { - Olanzapine improved glucose tolerance (via } \\
\text { OGTT administered 1-h after last dose) } \\
\text { - Matched by significant increase in serum insulin } \\
\text { in response to glucose bolus (attenuated } \\
\text { compared to vehicle treated rats) }\end{array}$ \\
\hline $\begin{array}{l}\text { Boyda et al. } \\
\text { (2012) [76] }\end{array}$ & $\begin{array}{l}\text { Female } \\
\text { Sprague- } \\
\text { Dawley rats }\end{array}$ & $\begin{array}{l}\text { Olanzapine; I.P. } \\
\text { 7.5, } 15 \mathrm{mg} / \mathrm{kg} \text {, Once }\end{array}$ & $\begin{array}{l}\text { - Increased fasting glucose levels, increased } \\
\text { serumin insulin levels } \\
\text { - Significantly impaired glucose tolerance (ipGTT) }\end{array}$ \\
\hline $\begin{array}{l}\text { Boyda et al. } \\
\text { (2014) [77] }\end{array}$ & $\begin{array}{l}\text { Female } \\
\text { Sprague- } \\
\text { Dawley rats }\end{array}$ & $\begin{array}{l}\text { Olanzapine; I.P.; } \\
\text { 7.5, } 15 \text { mg/kg; Once }\end{array}$ & $\begin{array}{l}\text { - No effect on fasting blood glucose levels } \\
\text { - Significantly increased fasting serum insulin } \\
\text { - Olanzapine decreased glucose tolerance (7.5, } 15 \\
\text { mg/kg; ipGTT) }\end{array}$ \\
\hline $\begin{array}{l}\text { Houseknecht } \\
\text { et al. }(2007) \\
{[60]}\end{array}$ & $\begin{array}{l}\text { Female } \\
\text { CD/Sprague- } \\
\text { Dawley Rats }\end{array}$ & $\begin{array}{l}\text { - } \text { Olanzapine; S.C. } \\
\text { - } 10 \mathrm{mg} / \mathrm{kg} \text {; Once (60 min } \\
\text { before dissection/ex } \\
\text { vivo incubation) } \\
\text { - } \text { Clozapine; S.C.; } \\
10 \mathrm{mg} / \mathrm{kg} \text {; Once ( } 60 \mathrm{~min} \\
\text { before dissection/ex } \\
\text { vivo incubation) }\end{array}$ & $\begin{array}{l}\text { No effect on in vitro basal or insulin-stimulated } \\
\text { glucose uptake in isolated epitrochlearis muscle }\end{array}$ \\
\hline
\end{tabular}


Table 4. Cont.

\begin{tabular}{|c|c|c|}
\hline \multicolumn{3}{|c|}{ A. Female Models } \\
\hline STUDY & MODEL & AP DOSE \\
\hline $\begin{array}{l}\text { Jassim et al. } \\
\text { (2012) [78] }\end{array}$ & $\begin{array}{l}\text { Female } \\
\text { Sprague- } \\
\text { Dawley rats }\end{array}$ & $\begin{array}{l}\text { - } \text { Olanzapine; I.P.; } \\
5 \mathrm{mg} / \mathrm{kg} \\
\text { - } \quad \text { Clozapine; I.P.; } \\
25 \mathrm{mg} / \mathrm{kg}\end{array}$ \\
\hline $\begin{array}{l}\text { Martins } \\
\text { et al. (2010) } \\
\text { [79] }\end{array}$ & $\begin{array}{l}\text { Female } \\
\text { C57/BL6 } \\
\text { Mice }\end{array}$ & $\begin{array}{l}\text { Olanzapine; I.P.; } 4.5 \mathrm{mg} / \mathrm{kg} \\
\text { Once }\end{array}$ \\
\hline $\begin{array}{l}\text { Wu et al. } \\
\text { (2014) [80] }\end{array}$ & $\begin{array}{l}\text { Female } \\
\text { Sprague- } \\
\text { Dawley Rats }\end{array}$ & $\begin{array}{l}\text { Olanzapine; S.C. } \\
10 \mathrm{mg} / \mathrm{kg} \text { (for ipGTT) } \\
1.5 \mathrm{mg} / \mathrm{kg}, 15 \mathrm{mg} / \mathrm{kg} \text { (for } \\
\text { HIEC) } \\
\text { Once }\end{array}$ \\
\hline
\end{tabular}

\section{EFFECT ON GLUCOSE METABOLISM}

- Increased serum glucose approximately $1 \mathrm{~h}$ posttreatment (olanzapine increased approximately $1 \mathrm{mmol} / \mathrm{L}$ (resolved by next time point-3 h))

- Olanzapine: No significant effect on serum insulin, or serum glucagon, slightly decreased gluconeogenic precursors

- Clozapine: increased glucagon 30 min posttreatment, increased gluconeogenic precursors

- Olanzapine increased blood glucose

- Serum insulin levels not reported

- No effect on fasting (overnight) blood glucose

- Large increase in fasting insulin levels

- Decreased glucose tolerance (ipGTT)

- High dose (15 mg.kg) but not low dose (1.5 mg/kg) increased insulin resistance (HIEC)

\section{B. Male Models}

\begin{tabular}{|c|c|c|c|}
\hline STUDY & MODEL & AP DOSE & EFFECT ON GLUCOSE METABOLISM \\
\hline $\begin{array}{l}\text { Albaugh } \\
\text { et al. (2011) } \\
\text { [48] }\end{array}$ & $\begin{array}{l}\text { Male } \\
\text { Sprague- } \\
\text { Dawley rats }\end{array}$ & $\begin{array}{l}\text { Olanzapine; Oral gavage } \\
10 \mathrm{mg} / \mathrm{kg} \\
2 \text { Doses (PM + AM } 2 \mathrm{~h} \\
\text { preceding experiments) }\end{array}$ & $\begin{array}{l}\text { - Increased blood glucose } 2 \mathrm{~h} \text { post-treatment in fed } \\
\text { and fasted ( } 5 \mathrm{~h}, 15 \mathrm{~h} \text { ) rats } \\
\text { - Increased insulin in fasted state, no affect in fed } \\
\text { state } \\
\text { - Impaired insulin sensitivity (HIEC) but insulin } \\
\text { signaling remained intact in response to } \\
\text { hyperinsulinemia }\end{array}$ \\
\hline $\begin{array}{l}\text { Albaugh } \\
\text { et al. (2012) } \\
\text { [81] }\end{array}$ & $\begin{array}{l}\text { Male } \\
\text { Sprague- } \\
\text { Dawley rats }\end{array}$ & $\begin{array}{l}\text { Olanzapine; Oral gavage } \\
4 \mathrm{mg} / \mathrm{kg} \\
2 \text { doses (PM and AM } 1 \mathrm{~h} \\
\text { preceding experiment) }\end{array}$ & $\begin{array}{l}\text { - Increased fasting glucose levels } \\
\text { - Decreased glucose tolerance (OGTT) and insulin } \\
\text { tolerance (ITT) } \\
\text { - Plasma insulin did not change during OGTT or in } \\
\text { response to olanzapine }\end{array}$ \\
\hline $\begin{array}{l}\text { Bush et al. } \\
\text { (2018) [82] }\end{array}$ & $\begin{array}{l}\text { Male } \\
\text { C57BL6J } \\
\text { mice }\end{array}$ & $\begin{array}{l}\text { Olanzapine; I.P. } \\
5 \text { mg/kg; Once }\end{array}$ & $\begin{array}{l}\text { - Increased blood glucose immediately post- } \\
\text { treatment } \\
\text { Prevented via activation of liver AMPK (via AICAR) }\end{array}$ \\
\hline $\begin{array}{l}\text { Castellani } \\
\text { et al. (2017) } \\
\text { [83] }\end{array}$ & $\begin{array}{l}\text { Male } \\
\text { C57BL6J } \\
\text { mice + male } \\
\text { Grgrc-/-mice }\end{array}$ & $\begin{array}{l}\text { Olanzapine; I.P. } \\
5 \mathrm{mg} / \mathrm{kg} \text {; Once }\end{array}$ & $\begin{array}{l}\text { - Increased blood glucose immediately post- } \\
\text { treatment } \\
\text { - No change in serum insulin, increased serum } \\
\text { glucagon } \\
\text { - Glucagon receptor knockout mice protected from } \\
\text { olanzapine-induced increase in blood glucose, } \\
\text { but not olanzapine-induced reductions insulin } \\
\text { tolerance }\end{array}$ \\
\hline
\end{tabular}


Table 4. Cont.

\begin{tabular}{|c|c|c|c|}
\hline \multicolumn{4}{|c|}{ B. Male Models } \\
\hline STUDY & MODEL & AP DOSE & EFFECT ON GLUCOSE METABOLISM \\
\hline $\begin{array}{l}\text { Castellani } \\
\text { et al. } \\
\text { (2018) [84] }\end{array}$ & $\begin{array}{l}\text { Male } \\
\text { C57BL6J } \\
\text { mice }\end{array}$ & $\begin{array}{l}\text { Olanzapine; I.P.; } 5 \mathrm{mg} / \mathrm{kg} \text {; } \\
\text { Once }\end{array}$ & $\begin{array}{l}\text { - Increased blood glucose immediately post- } \\
\text { treatment, no change in serum insulin }\end{array}$ \\
\hline $\begin{array}{l}\text { Chintoh } \\
\text { et al. } \\
(2008) \text { [85] }\end{array}$ & $\begin{array}{l}\text { Male } \\
\text { Sprague- } \\
\text { Dawley rats }\end{array}$ & $\begin{array}{l}\text { Olanzapine; S.C. } \\
3 \mathrm{mg} / \mathrm{kg} \text {; Once }\end{array}$ & $\begin{array}{l}\text { - Increased blood glucose } \\
\text { - Decreased insulin release in response to glucose } \\
\text { bolus (lower insulin and c-peptide levels during } \\
\text { hyperglycemic clamp) } \\
\text { - Increased insulin resistance (HIEC- increased } \\
\text { glucose production/decreased glucose uptake) }\end{array}$ \\
\hline $\begin{array}{l}\text { Chintoh } \\
\text { et al., (2009) } \\
\text { [86] }\end{array}$ & $\begin{array}{l}\text { Male } \\
\text { Sprague- } \\
\text { Dawley rats }\end{array}$ & $\begin{array}{l}\text { - } \text { Clozapine; S.C.; } \\
10 \mathrm{mg} / \mathrm{kg} \\
\text { - } \text { Olanzapine; S.C.; } \\
3.0 \mathrm{mg} / \mathrm{kg} \\
\text { - } \quad \text { Risperidone; S.C.; } \\
1 \mathrm{mg} / \mathrm{kg} \\
\text { - Ziprasidone; S.C.; } \\
3 \mathrm{mg} / \mathrm{kg} \\
\text { - } \text { Haloperidol; S.C.; } \\
0.25 \mathrm{mg} / \mathrm{kg} \\
\text { Once }\end{array}$ & $\begin{array}{l}\text { - Olanzapine and clozapine decreased insulin } \\
\text { sensitivity (HIEC), increased hepatic glucose } \\
\text { production } \\
\text { - Olanzapine and clozapine decreased insulin } \\
\text { secretion in response to glucose bolus } \\
\text { (hyperglycemic clamp) }\end{array}$ \\
\hline $\begin{array}{l}\text { Girault et al. } \\
\text { (2012) [87] }\end{array}$ & $\begin{array}{l}\text { Male Wistar } \\
\text { Han rats }\end{array}$ & $\begin{array}{l}\text { - Olanzapine; } \\
\text { intragastirc; } 3 \mathrm{mg} / \mathrm{kg} / \mathrm{h} \text {; } \\
\text { Once } \\
\text { - } \text { Olanzapine; ICV; } \\
30 \mathrm{mg} / \mathrm{kg} / \mathrm{h} \text {, Once } \\
\end{array}$ & $\begin{array}{l}\text { - Increased blood glucose levels, no change in } \\
\text { plasma insulin, corticosterone } \\
\text { - ICV olanzapine had no effect on blood glucose } \\
\text { levels or endogenous glucose production, insulin, } \\
\text { corticosterone levels }\end{array}$ \\
\hline $\begin{array}{l}\text { Hahn et al. } \\
\text { (2014) [88] }\end{array}$ & $\begin{array}{l}\text { Male } \\
\text { Sprague- } \\
\text { Dawley rats }\end{array}$ & $\begin{array}{l}\text { Olanzapine; ICV; } 75 \text { ug; } \\
\text { Once }\end{array}$ & $\begin{array}{l}\text { - Decreased insulin secretion (decreased insulin } \\
\text { and c-peptide levels during hyperglycemic } \\
\text { clamp) } \\
\text { - Increased blood glucose levels (lower glucose } \\
\text { infusion rate to reach hyperglycemia in response } \\
\text { to olanzapine treatment) } \\
\text { - No effect on insulin resistance (HIEC) }\end{array}$ \\
\hline $\begin{array}{l}\text { Houseknecht } \\
\text { et al. (2007) } \\
{[60]}\end{array}$ & $\begin{array}{l}\text { Male Wistar } \\
\text { Han rats }\end{array}$ & $\begin{array}{l}\text { - } \text { Clozapine; S.C.; 1, 3.2, } \\
10 \mathrm{mg} / \mathrm{kg} \text {; Once } \\
\text { - } \text { Olanzapine; S.C.; 1, 3.2, } \\
10 \mathrm{mg} / \mathrm{kg} ; \text { Once } \\
\text { - } \text { Risperidone; S.C.; } \\
2 \text { mg/kg; Once } \\
\text { - Ziprasidone; S.C.; 3.2, } \\
\text { 10, } 32 \mathrm{mg} / \mathrm{kg} \text {; Once }\end{array}$ & $\begin{array}{l}\text { Clozapine (3.2, } 10 \mathrm{mg} / \mathrm{kg}) \text { : Increased insulin } \\
\text { resistance (HIEC) } \\
\text { - Olanzapine (3.2, } 10 \mathrm{mg} / \mathrm{kg}) \text { : Increased insulin } \\
\text { resistance (HIEC) } \\
\text { - Risperidone: No effect on insulin sensitivity } \\
\text { (HIEC) } \\
\text { - Ziprasidone: No effect on insulin sensitivity } \\
\text { (HIEC) }\end{array}$ \\
\hline
\end{tabular}


Table 4. Cont.

\begin{tabular}{|c|c|c|c|}
\hline \multicolumn{4}{|c|}{ B. Male Models } \\
\hline STUDY & MODEL & AP DOSE & EFFECT ON GLUCOSE METABOLISM \\
\hline $\begin{array}{l}\text { Ikegami } \\
\text { et al. (2013) } \\
\text { [89] }\end{array}$ & $\begin{array}{l}\text { Male ICR } \\
\text { Mice }\end{array}$ & $\begin{array}{l}\text { Olanzapine; ICV; 5, 10, } \\
15 \text { nmol; Once }\end{array}$ & $\begin{array}{l}\text { - Dose dependent increase in blood glucose at } \\
\text { doses of } 10 \text { and15 nmol } \\
\text { - No change in blood insulin }\end{array}$ \\
\hline $\begin{array}{l}\text { Ikegami } \\
\text { et al. }(2013) \\
{[90]}\end{array}$ & $\begin{array}{l}\text { Male ICR } \\
\text { mice }\end{array}$ & $\begin{array}{l}\text { - Olanzapine; I.P; } \\
\text { 0.3,1,3,5 mg/kg, Once } \\
\text { - Olanzapine; ICV; } 10 \text {, } \\
15 \text { nmol; Once }\end{array}$ & $\begin{array}{l}\text { - I.P. dose ( } 3,5 \mathrm{mg} / \mathrm{kg}) \text { : Decreased glucose tolerance } \\
\text { (ipGTT) } \\
\text { ICV dose: Decreased glucose tolerance (ipGTT) } \\
\text { Changes involve activation of hypothalamic AMPK } \\
\text { - No effect of olanzapine on insulin or glucagon } \\
\text { levels ( } 20 \text { min post-treatment) }\end{array}$ \\
\hline $\begin{array}{l}\text { Ikegami } \\
\text { et al. } \\
\text { (2013) [91] }\end{array}$ & $\begin{array}{l}\text { Male ICR } \\
\text { mice, } 6 \text { weeks } \\
\text { old }\end{array}$ & $\begin{array}{l}\text { - Olanzapine; I.P; } \\
\text { 0.3,1,3,5 mg/kg, Once } \\
\text { - Olanzapine; ICV; } 10 \text {, } \\
15 \text { nmol; Once }\end{array}$ & $\begin{array}{l}\text { - I.P. treatment increased blood glucose in fed and } \\
\text { overnight fasted mice } \\
\text { - ICV treatment increased blood glucose in fed } \\
\text { mice only } \\
\text { - Involves AMPK activation at hypothalamus and } \\
\text { beta-adrenergic activation }\end{array}$ \\
\hline $\begin{array}{l}\text { Klingerman } \\
\text { et al. (2015) } \\
\text { [92] }\end{array}$ & $\begin{array}{l}\text { Male } \\
\text { Sprague- } \\
\text { Dawley rats }\end{array}$ & $\begin{array}{l}\text { - } \text { Olanzapine; ICV (3rd } \\
\text { ventricle); 0.1, 0.2, 0.3, } \\
0.44 \mathrm{mg} / \mathrm{kg} \\
\text { - } \text { Olanzapine; ICV (lateral } \\
\text { ventricle); } 0.44, \\
1.8 \mathrm{mg} / \mathrm{kg} \\
\text { - } \text { Olanzapine; Oral } \\
\text { gavage; 0.44, } 1 \text {, } \\
3,10 \mathrm{mg} / \mathrm{kg} \text { ) } \\
\end{array}$ & $\begin{array}{l}\text { - ICV: Increased blood glucose } 30 \mathrm{~min} \text { post- } \\
\text { treatment to } 3 \mathrm{rd} \text { ventricle }(0.3 \mathrm{mg} / \mathrm{kg}, 0.44 \mathrm{mg} / \mathrm{kg}) \\
\text { - ICV: Increased blood glucose } 30 \mathrm{~min} \text { post- } \\
\text { treatment to lateral ventricle }(1.8 \mathrm{mg} / \mathrm{kg}) \\
\text { - Increased blood glucose in fasted ( } 4-\mathrm{h}) \mathrm{rats} \\
30 \mathrm{~min} \text { post-treatment }(3 \mathrm{mg} / \mathrm{kg}, 10 \mathrm{mg} / \mathrm{kg}) \text { and } \\
1 \mathrm{~h} \text { post-treatment }(10 \mathrm{mg} / \mathrm{kg})\end{array}$ \\
\hline $\begin{array}{l}\text { Kowalchuk } \\
\text { et al. (2017) } \\
\text { [93] }\end{array}$ & $\begin{array}{l}\text { Male } \\
\text { Sprague- } \\
\text { Dawley rats }\end{array}$ & $\begin{array}{l}\text { Olanzapine; S.C.; } 2 \text { mg/kg } \\
\text { Once }\end{array}$ & $\begin{array}{l}\text { - No effect of olanzapine during euglycemic- } \\
\text { pancreatic clamp (somatostatin to block } \\
\text { endogenous insulin secretion, exogenous insulin } \\
\text { replaced at basal levels) }\end{array}$ \\
\hline $\begin{array}{l}\text { Martins } \\
\text { et al. }(2010) \\
{[79]}\end{array}$ & $\begin{array}{l}\text { Male } \\
\text { Sprague- } \\
\text { Dawley Rats }\end{array}$ & $\begin{array}{l}\text { - Olanzapine; primed } \\
\text { continuous IV } \\
\text { infusion; } 1 \mathrm{mg} / \mathrm{kg} / \mathrm{h} \\
\text { Once } \\
\text { - Olanzapine; ICV; a } \\
\text { bolus of } 110 \mathrm{~g} \text { and } \\
73.4 \mathrm{~g} / \mathrm{h} \\
\text { Once }\end{array}$ & $\begin{array}{l}\text { - Increased blood glucose levels, no change in } \\
\text { plasma insulin } \\
\text { - Increased rate of glucose production, decreased } \\
\text { rate of uptake (HIEC) } \\
\text { - Increased endogenous glucose production at } \\
\text { liver and increased p-AMPK at hypothalamus }\end{array}$ \\
\hline
\end{tabular}


Table 4. Cont.

\begin{tabular}{|c|c|c|c|}
\hline \multicolumn{4}{|c|}{ B. Male Models } \\
\hline STUDY & MODEL & AP DOSE & EFFECT ON GLUCOSE METABOLISM \\
\hline $\begin{array}{l}\text { Nagata et al. } \\
\text { (2016) [94] }\end{array}$ & $\begin{array}{l}\text { Male Wistar } \\
\text { Rats }\end{array}$ & $\begin{array}{l}\text { Olanzapine ;I.V.; 2.5, 5, } 10 \\
\mathrm{mg} / \mathrm{kg} \\
\text { Once }\end{array}$ & $\begin{array}{l}\text { - High dose of olanzapine (10 mg/kg) increased } \\
\text { blood glucose and blood insulin (max 1 h post- } \\
\text { AP) } \\
\text { - Increased blood cortisol but no change in serum } \\
\text { glucagon } \\
\text { - Effect blocked by treatment with adrenergic } \\
\text { receptor antagonist propranolol }\end{array}$ \\
\hline $\begin{array}{l}\text { Smith et al. } \\
\text { (2008) [54] }\end{array}$ & $\begin{array}{l}\text { Male } \\
\text { Sprague- } \\
\text { Dawley rats }\end{array}$ & $\begin{array}{l}\text { - Haloperidol; } 0.25 \mathrm{mg} / \mathrm{kg} \\
\text { - } \text { Quetiapine;10 mg/kg } \\
\text { - Clozapine;10 mg/kg } \\
28 \text { days }\end{array}$ & $\begin{array}{l}\text { - Blood glucose and plasma insulin levels were } \\
\text { significantly increased by } 1 \mathrm{~h} \text { after haloperidol, } \\
\text { quetiapine or clozapine injections } \\
\text { - Decreased glucose tolerance (via decreased } \\
\text { glucose clearance in response to quetiapine and } \\
\text { clozapine) } \\
\text { - Increased hepatic glucose output (PTT) }\end{array}$ \\
\hline $\begin{array}{l}\text { Townsend } \\
\text { et al. (2018) } \\
\text { [61] }\end{array}$ & $\begin{array}{l}\text { Male } \\
\text { C57BL6J } \\
\text { mice }\end{array}$ & $\begin{array}{l}\text { Olanzapine; I.P.; } 5 \mathrm{mg} / \mathrm{kg} \\
\text { Once }\end{array}$ & $\begin{array}{l}\text { - Increased blood glucose post-treatment } \\
\text { - Potentiated with } 4 \text { week high fat feeding } \\
\text { - Increased gluconeogenesis, decreased insulin } \\
\text { sensitivity and signaling }\end{array}$ \\
\hline
\end{tabular}

AP: antipsychotic, iPGTT: intraperitoneal glucose tolerance test, HIEC: hyperinsulinemic-euglycemic clamp, PTT: pyruvate tolerance test.

Acute AP-treatment on changes in blood glucose in male models

A single treatment of olanzapine has been shown to rapidly and significantly increase blood glucose in male mice [61,82-84,89,91] and rats $[48,81,85,87,88,92]$, with peak blood glucose occurring approximately 1-2 $\mathrm{h}$ post treatment (Table 4B). Indeed, both a single dose of olanzapine (administered via subcutaneous injection [85], intravenous infusion [79,94], intragastric infusion [87], oral gavage [85]) as well as a twice daily dose via oral gavage (one dose in the evening, one dose one hour preceding measures) [48,81] increased blood glucose in male rats. Similarly, a single injection of olanzapine (intraperitoneal injection [8284,89] or intracerebral ventricular infusion [79,89,91]) in male mice significantly increased blood glucose levels compared to vehicle treated mice. Interestingly, olanzapine-induced hyperglycemia is more pronounced in the fed compared to the fasted state. An intraperitoneal injection of olanzapine in fed animals resulted in a greater increase in blood glucose the hours post-injection compared to fasted male mice [90]. Similarly, centrally-administered olanzapine only increased blood glucose in fed, but not fasted animals, suggesting a protective role for metabolic factors altered by fasting/feeding in olanzapine-mediated glucose dysregulation [91]. 
Serum insulin levels in male models of acute AP-treatment

Notably, despite rapid increases in blood glucose, serum insulin levels are not consistently altered in either rats or mice treated with olanzapine $[48,84,89,87,79]$ (Table 4B). This raises the possibility that, in male rats, appropriate insulin responses to elevations in glucose are inhibited by APs. This is supported by findings demonstrating olanzapine associated reductions in insulin responses (i.e., decreased serum insulin and cpeptide levels) following a bolus of glucose, or during hyperglycemic clamps $[85,88,86]$. Similarly, serum insulin did not change in response to an oral glucose tolerance test whereas olanzapine treatment worsened glucose tolerance (i.e., blood glucose remained significantly elevated over time in response to oral glucose bolus) [81]. Moreover, during a pancreatic-euglycemic clamp during which insulin levels are exogenously infused to basal pre-prandial fed conditions, olanzapine had no effect on insulin sensitivity [93]. This suggests that when pancreatic insulin secretion is artificially maintained the effects of olanzapine on glucose metabolism are minimized. As such the inability of male mice and rats to preserve insulin responses in the face of elevated blood glucose levels may leave them susceptible to AP-induced hyperglycemia.

Insulin sensitivity in male models in response to acute AP-treatment

Alongside impaired insulin secretion and elevated blood glucose levels, acute olanzapine treatment has been shown to impair whole body insulin sensitivity. As measured by a hyperinsulinemic-euglycemic (HIEC) clamp, the gold standard technique to assess whole body insulin sensitivity, acute exposure to a subcutaneous bolus of olanzapine significantly decreased insulin sensitivity in male rats [60,81,85,86] (Table 4B). This aligns with work demonstrating worsened insulin tolerance following a bolus of olanzapine in male mice $[82,83]$ and rats [81]. Interestingly, some [79], but not all [88] have shown that central administration of olanzapine also worsens insulin sensitivity in male rats during a HIEC.

Acute clozapine treatment has been similarly shown to impair whole body insulin sensitivity as measured by a HIEC. Treatment with a subcutaneous bolus of clozapine resulted in increased hepatic glucose production, as was noted with olanzapine treatment, in male rats $[60,86]$.

Although insulin resistance is consistently reported in response to acute AP-dosing, it is unlikely that it exists as an initiating factor in glycemic disturbances. Previous reports have instead highlighted an integral role for catecholamines and glucagon in the activation of hepatic glucose production by olanzapine [94,95]. Indeed, olanzapine-induced increases in blood glucose are ablated in glucagon receptor knockout mice, despite the onset of olanzapine-induced insulin resistance (as measured by an insulin tolerance test). In this study, olanzapine also induced an exaggerated rise in blood glucose in response to a bolus of 
pyruvate in wildtype but not glucagon receptor knockout mice, suggesting increased hepatic gluconeogenesis by olanzapine only in the presence of active glucagon receptors [95]. This aligns with work from Nagata et al. who demonstrated that a 30 min pretreatment with betaadrenergic receptor antagonist propranolol can mitigate olanzapine (i.v. treatment, $10 \mathrm{mg} / \mathrm{kg}$ )-induced increases in blood glucose [94]. This highlights the ability to recover glucose homeostasis in the absence of improved insulin sensitivity.

Blood glucose and serum insulin levels in female models of acute-AP treatment

In contrast to male models, increases in fasting blood glucose are not as consistently observed in female rats following acute olanzapine treatment $[33,80]$ (Table $4 \mathrm{~A}$ ). Unlike the case in male rats, twice daily acute oral gavage with olanzapine over a $29 \mathrm{~h}$ exposure period significantly decreased fasting blood glucose levels in female rats [33]. Similarly, a single dose of olanzapine administered via subcutaneous injection did not alter blood glucose levels one hour post-treatment in females [77,80]. Interestingly, although olanzapine did not raise blood glucose, serum insulin levels were significantly elevated post-olanzapine treatment [77,80]. In contrast, Jassim et al. reported blood glucose levels to be increased approximately $1 \mathrm{mmol} / \mathrm{L}$ one hour post treatment in female rats, and this occurred in the absence of changes in serum insulin [78]. This finding aligns with work conducted by Martins et al. [79] who showed an increase in blood glucose in fasted female C57/BL6 mice treated with an intraperitoneal bolus of olanzapine $(4.5 \mathrm{mg} / \mathrm{kg})$. Changes in serum insulin in these mice were not reported. In agreement with this work a single study has shown olanzapine to significantly increase both blood glucose and serum insulin levels in female rats [76]. While this effect is often seemingly more subtle than olanzapine-induced hyperglycemia observed in studies using male mice (increasing approximately $5 \mathrm{mmol} / \mathrm{L}$ compared to vehicle treated mice) [82,84,90], further work is required to directly compare changes in blood glucose in male and female preclinical models. It would appear that females may be protected against SGA-induced hyperglycemia, and this may be driven by increased insulin secretion (or responses).

\section{Glucose tolerance in female models of acute AP treatment}

In comparison to male models, AP-treated female rodents have shown less consistent responses to a glucose challenge (Table 4A). In a study by Albaugh et al., acute oral olanzapine ( $4 \mathrm{mg} / \mathrm{kg}$ ) administration (in addition to lowering of fasting glucose levels) was associated with improved glucose tolerance, and increases in serum insulin levels during an oral glucose tolerance test [33]. This effect appeared to be dependent on the dose and route of administration of olanzapine. Higher doses $(7.5 \mathrm{mg} / \mathrm{kg}$ and $15 \mathrm{mg} / \mathrm{kg}$, and $10 \mathrm{mg} / \mathrm{kg}$ ) administered via intraperitoneal and 
subcutaneous injections respectively worsened glucose tolerance in response to an intraperitoneal injection of glucose [76,80,77]. The inconsistencies in these results could highlight specific dose and route of administration effects of olanzapine treatment in female rodents.

Insulin resistance in female models of acute AP treatment

In line with dose-dependent effects on glucose dysregulation in female rats, $\mathrm{Wu}$ et al. utilized a hyperinsulinemic-euglycemic clamp (HIEC) to identify significant increases in insulin resistance in response to $15 \mathrm{mg} / \mathrm{kg}$ bolus of olanzapine, but found no effect of olanzapine at a dose of $1.5 \mathrm{mg} / \mathrm{kg}$ (both treatments administered via subcutaneous injection) [80] (Table 4A). Similar to male rats, glucose dysregulation appears to involve unchecked glucose production, rather than impaired insulin stimulated glucose uptake. Specifically, Houseknecht et al. revealed that epitrochlearis muscle incubated ex vivo $1 \mathrm{~h}$ post-olanzapine treatment (10 $\mathrm{mg} / \mathrm{kg}$, subcutaneous injection) from female rats showed basal and insulin-stimulated glucose uptake to be intact [60] (Table 4A).

In summary, acute AP-treatment in preclinical models reveals males are susceptible to dysregulated blood glucose independent of changes in body composition, an effect less consistently observed in female models. These results suggest sex differences in insulin metabolism.

\section{Potential Mechanisms Underlying Observed Sex Differences in AP-Induced Adiposity and Glucose Dysregulation}

A number of potential mechanisms have been proposed to explain adverse metabolic side effects of APs, but few directly address how these mechanisms may differentially affect males and females. Below, we have briefly highlighted four areas of research that consider the importance of sex differences in proposed mechanisms underlying AP-induced metabolic side effects: food intake, energy expenditure, the influence of sex hormones, aging, drug metabolism and the gut microbiome composition.

\section{Food intake}

Among the several mechanisms involved in regulation of body weight, changes in food intake are considered an integral factor driving APmediated changes in body weight, particularly in preclinical studies. Specifically, increases in body weight were consistently matched by increases in food intake in female rats and mice in response to AP treatment [34,35,38,40,42-46,56,57,59], while this feeding effect was absent in female mice [33] and male rats and dogs who remained body weight stable [33,47-50,53]. In male rats, olanzapine treatment has been shown to increase meal size and to decrease feeding rate [23], while olanzapine and clozapine treatment have demonstrated increased preference for fat intake [96], suggesting a hedonic effect of these APs in 
the absence of changes in overall food intake. In clinical studies, data does support an increase in appetite, motivation to eat, and food consumption associated with APs [97,98], but there has been less attention to the impact of medications on these factors and how they may differ by sex. Factors driving these changes in regulation of food intake remain to be fully understood but could involve changes in insulin action, hormone signaling [99], and/or nutrient sensing [100].

\section{Energy expenditure}

In addition to changes in food intake, changes in energy expenditure are critical to understanding the effects of APs on whole body energy balance. Indeed, resting energy expenditure was increased in healthy male volunteers treated with olanzapine, although these men also displayed increased food intake and body weight at the end of the treatment period (13 days) [101]. In contrast, a smaller study examining nine participants (6 men and 3 women) demonstrated that approximately 12 weeks of olanzapine treatment had no effect on resting energy expenditure in conjunction with increased body weight [102]. How sex might effect AP-induced changes in energy expenditure has not been well-investigated, but should be considered more carefully in future work. Male and female participants have been previously reported to display differences in resting energy expenditure, however this sex-effect was lost when body weight was controlled for [103]. Moreover sex hormones (e.g., estrogen and testosterone) are well appreciated to be involved in the regulation of resting energy expenditure [104], suggesting that AP-induced perturbations in energy expenditure may differ between men and women.

Preclinical models of AP treatment have shown similar effects on energy expenditure. Female C57BL6 mice fed a high fat diet containing olanzapine for 3 days showed decreased physical activity yet increased heat production and energy expenditure in response to the AP treatment. Resting energy expenditure (RER) was not affected by olanzapine treatment in these mice. This effect was maintained in male C57BL/6 mice who displayed increased energy expenditure and decreased physical activity [105]. Townsend et al. similarly showed that oxygen consumption was increased in high fat diet fed male mice treated acutely with olanzapine [61]. Acute olanzapine treatment in male rats was also shown to increase heat production in the light phase (when animals are expected to be sleeping) but not in the dark (active) phase [106]. Changes in energy expenditure could reflect innate metabolic changes in response to AP treatment, but may also be confounded by preclinical housing conditions. Emerging literature has specifically highlighted the metabolic consequences (i.e., increased resting energy expenditure) of housing animals at standard conditions, slightly below thermoneutrality [107,108]. It is possible that olanzapine-induced weight loss in male rodents housed at standard conditions are confounded by increased 
resting metabolic rates in response to heat production. How housing below the thermal neutral temperatures may affect female rodents differently from males and the consequences for metabolic perturbations such as AP treatment remains to be examined.

\section{Sex hormones}

Sex hormones are intriguing as potential moderators of adverse metabolic effects due to APs. Most obviously, the decline of estrogen in menopause is known to be associated with decreased subcutaneous adipose tissue and increased visceral tissue in females [109] that mirrors AP-induced changes in adiposity. Reviews by Lizcano and Mauvais highlight the role of estrogen in regulating adipose tissue distribution, appetite, satiety, energy regulation, and fat metabolism [109,110]. A role for estrogen has also been identified for the maintenance of glucose homeostasis [111].

Preclinical models have demonstrated an effect of estrogen on APmediated accumulation of adipose tissue, changes in feeding and glucose homeostasis, in ovariectomized rats treated with olanzapine $[35,46,112,113]$. For example, the AP sulpiride, like olanzapine, has been observed to cause weight gain in female, but not male rats [114]. Shimizu et al. expanded upon this observation to measure changes in weight and food intake in female rats post ovariectomy, and again following estrogen supplementation [114]. They found that post ovariectomy, the hyperphagia and weight gain induced by sulpiride pre-ovariectomy was absent, but that it could be restored after 14 days of estradiol injections. Similarly, Skrede et al. [46] demonstrated that the orexigenic effects of olanzapine and drug-induced body weight gain were attenuated in ovariectomized rats compared to sham-operated animals. This effect was reversed following 8-day estradiol replacement. A clinical study that included 20 female patients with schizophrenia, taking either olanzapine or risperidone for 3 months, noted a significant correlation between estradiol and increases in BMI. The authors suggested that this supported previous literature suggesting that APs affect the hypothalamic-pituitarygonadal axis [115]. Together this work identifies estrogen as a factor promoting chronic olanzapine-induced increases in body weight and highlights a role for reproductive status on AP-induced weight gain and/or vice versa.

Finally, estrogen has been shown to intimately regulate glucose metabolism, in part via stimulation of insulin secretion and suppression of glucagon release [116]. It is possible that the dampened effect of APs on acute glucose dysregulation in female rodents could involve the ability of estrogen to enhance glucose-stimulated insulin release [117]. While male mice seem to lack the appropriate ability to release insulin in response to increased glucose levels [84], it is possible estrogen preserves the insulin response in female rodents, though this has not been investigated. Moreover, given the integral role for glucagon action in 
olanzapine-mediated hyperglycemia [95], estrogen mediated reductions in glucagon secretion [116] could similarly attenuate glycemic dysregulation post-acute olanzapine. More work is required to directly assess the effects of estrogen on AP-induced metabolic deregulation.

\section{Aging}

The proposed role for estrogen highlights the effect of age and reproductive status on AP-induced metabolic responses. Post-menopause a decline in the response to AP treatment has been reported in women with schizophrenia [118]. Similarly, premenopausal women show significantly better treatment response to olanzapine and haloperidol treatment than post-menopausal women [119]. Elderly individuals also display increased plasma levels of olanzapine (weight-adjusted) compared to younger olanzapine-treated patients, suggesting unique AP pharmacokinetics across the lifespan [120].

Independent of AP exposure, menopausal status is known to dramatically affect metabolic health, including changes in adiposity. While premenopausal women are prone to accumulate subcutaneous and gluteal adipose tissue, men and post-menopausal women accumulate visceral adipose tissue in the abdominal region [121]. Similarly, menopause has been shown to influence the development of type 2 diabetes [122]; an effect which could be potentiated with AP treatment. Moreover, gradual decline of testosterone observed in aging men is similarly associated with distinct alterations in body composition. Specifically, the loss of testosterone is associated with a loss of lean mass, accumulation of central/visceral adiposity, and decreased mobility [123]. How this could interact with APs to influence metabolic health remains to be investigated.

\section{Drug metabolism}

Sex specific metabolic responses to AP treatment could also reflect well established differences in pharmacokinetics between men and women [124]. Men are reported to have a higher clearance of olanzapine (approximately 38\%) compared to women [125] as well as increased activity of cytochrome P450 (CYP) 1A2 (the hepatic enzyme predominantly responsible for olanzapine breakdown to metabolites in the liver) [126,127], which could in part explain sex-specific responses to AP treatment. Regulation of drug metabolism is known to involve rate and mode of absorption, levels of hepatic phase I enzymes, and mode of elimination, all of which are altered by sex and influenced by sex hormones, age and body composition [125,128]. Exogenous increases in estrogen (via oral contraceptive) have shown to significantly decrease CYP 1A2 levels in treated compared to untreated women highlighting the effect of sex hormones on CYP 1A2 activity and risk for decreased AP clearance [127]. How AP-induced changes in body composition and 
metabolism may further confound innate sex differences in drug metabolism over the course of treatment is not yet known.

\section{Microbiome}

Another mechanism that may underlie sex differences in AP-induced metabolic disorders receiving increasing attention is gut microbiome dysbiosis (i.e., a pronounced shift and subsequent imbalance in gut microbiota). Recent in vitro data demonstrates that both first and second generation APs (despite their differences), exhibit direct activity against common commensal gut microbes [129]. Gut dysbiosis associated with AP treatment has been shown to lead to increased systemic inflammation [130], altered structure and function of the intestinal mucosal barrier [131], and disrupted energy metabolism [132], all of which consequently lead to the development of obesity and metabolic disturbances [133-135]. Recent preclinical research in germ-free mice, or mice raised in a sterile environment, has also noted that the presence of a microbiome is essential for AP-induced weight gain [136,137].

With respect to clinical microbiome research, Bahr et al. investigated the association of risperidone and AP induced weight gain in relation to the gut microbiome [138]. They observed that chronic risperidone treatment was associated with an increase in body mass index and a significantly lower ratio of the bacterial phyla Bacteroidetes: Firmicutes, as compared with AP-naïve psychiatric controls. Additionally, Bahr et al. found the gut microbiota of participants treated with risperidone to be enriched for pathways implicated in weight gain, such as short-chain fatty acid production. In a separate study comparing the gut microbiota of individuals treated with APs to psychiatric participants treated with mood stabilizers, Flowers et al. found AP treatment to be associated with higher body mass index and decreased bacterial species richness in feces [139]. AP treatment was also associated with medication-specific decreases in Akkermansia muciniphilia, a bacterial species routinely associated with anti-inflammatory properties and metabolic protective effects [140]. Finally, a study by Yuan et al. found risperidone treatment over the course of 24 weeks to results in a significant increase in the number of fecal Bifidobacterium spp. and Escherichia coli in study participants. This was associated with obesity [141].

With regards to the role of sex in this interplay between metabolic disturbances and gut microbiome-associated dysbiosis, both Yuan et al. [28] and Flowers [139] did not observe different metabolic outcomes between males and females, while Bahr et al. only assessed adolescent male participants. However, an additional study conducted by Flowers et al. in 2019 that recruited patients with schizophrenia or bipolar disorder did observe decreased species richness in females on SGAs compared to females on mood stabilizers. This relationship between species richness and APs was not observed in males [142]. Due to the limited studies assessing this interrelationship, further investigation is needed to better 
explain the influence of sex on the interaction between AP-associated microbiome dysbiosis and metabolic response.

\section{CONCLUSIONS}

In summary, we reviewed observed associations between sex, adiposity, and changes in glucose metabolism as associated with AP use in preclinical and clinical studies. Despite some disagreement among clinical data, female sex was more often associated with greater weight gain in patients on AP in clinical research studies, and this finding was consistently replicated in preclinical research with rodents, particularly upon exposure to olanzapine. With respect to changes in fat distribution patterns following AP exposure, there is a small body of clinical research studies suggesting that, despite females gaining more total weight due to APs, males are more likely to accumulate metabolically adverse visceral adipose tissue when treated with APs. In preclinical models, this is supported by AP-related increases in visceral fat mass, despite reports of weight loss or lack of weight gain in male models. Much of our discussion on AP-related disturbances in glucose homeostasis stemmed from preclinical studies, which suggest that males could be more susceptible to glucose dysregulation independent of changes in body composition as compared to females. This however remains to be replicated in humans. Proposed mechanisms underlying the differential metabolic responses by sex to APs include variable changes in food intake patterns, effects on the microbiome, and the influence of sex hormones. The preclinical and clinical research studies considered here identified sexually divergent metabolic responses to chronic and acute AP treatment though both sexes suffer from adverse metabolic complications.

\section{AUTHOR CONTRIBUTIONS}

MKH, LC and KW conceptualized this review article, and contributed to preparation of the first draft. All authors participated in the literature searches and contributed to the organization and writing of the paper.

\section{CONFLICTS OF INTEREST}

LNC, WBM, KACD, SAF, KMW, DCW: declare(s) that they have no conflicts of interest; MKH receives consultation fees from Alkermes.

\section{FUNDING}

KMW is supported by a training grant through the National Center for Advancing Translational Sciences (NCATS, grant number KL2TR002241). LNC is supported by the Bebensee Schizophrenia Research Scholarship.

KACD is supported by the supported by the Cleghorn Fellowship (University of Toronto), Canadian Institutes of Health Research (Canada Graduate Scholarship Masters Award), and CAMH Discovery Fund. 
DCW is a Tier II Canada Research Chair in Lipids, Metabolism and Health.

$\mathrm{MKH}$ has received research support from the Canadian Institutes of Health Research (grant number: PJT-153262), the Banting and Best Diabetes Centre, U of T, and the Banting Research Foundation.

\section{REFERENCES}

1. Konstantinidis A, Papageorgiou K, Grohmann R, Horvath A, Engel R, Kasper $S$. Increase of antipsychotic medication in depressive inpatients from 2000 to 2007: results from the AMSP International Pharmacovigilance Program. Int J Neuropsychopharmacol. 2012;15:449-57.

2. Morin AK. Off-label use of atypical antipsychotic agents for treatment of insomnia. Ment Heal Clin. 2014;4:65-72.

3. Harrison JN, Cluxton-Keller F, Gross D. Antipsychotic medication prescribing trends in children and adolescents. J Pediatr Health Care. 2012;26:139-45.

4. Vitiello B, Correll C, van Zwieten-Boot B, Zuddas A, Parellada M, Arango C. Antipsychotics in children and adolescents: Increasing use, evidence for efficacy and safety concerns. Eur Neuropsychopharmacol. 2009;19:629-635.

5. Kahn RS, Fleischhacker WW, Boter H, Davidson M, Vergouwe Y, Keet IP, et al. Effectiveness of antipsychotic drugs in first-episode schizophrenia and schizophreniform disorder: an open randomised clinical trial. Lancet. 2008;371:1085-97.

6. Bergman RN, Ader M. Atypical Antipsychotics and Glucose Homeostasis. J Clin Psychiatry. 2005;66:504-14.

7. Gibson K, Cde R, Dietitian S. Canadian Diabetes Association 2008 Clinical Practice Guidelines for the Prevention and Management of Diabetes in Canada. Available from: http://guidelines.diabetes.ca/docs/CPG-2018-fullEN.pdf. Accessed 2019 Aug 12.

8. Oriot P, Feys J-L, Mertens de Wilmars S, Misson A, Ayache L, Fagnart O, et al. Insulin sensitivity, adjusted beta-cell function and adiponectinaemia among lean drug-naive schizophrenic patients treated with atypical antipsychotic drugs: a nine-month prospective study. Diabetes Metab. 2008;34:490-6.

9. Galling B, Roldán A, Nielsen RE, Nielsen J, Gerhard T, Carbon M, et al. Type 2 Diabetes Mellitus in Youth Exposed to Antipsychotics: A Systematic Review and Meta-analysis. JAMA Psychiatry. 2016;73:247-59.

10. Rajkumar AP, Horsdal HT, Wimberley T, Cohen D, Mors O, Børglum AD, et al. Endogenous and Antipsychotic-Related Risks for Diabetes Mellitus in Young People With Schizophrenia: A Danish Population-Based Cohort Study. Am J Psychiatry. 2017;174:686-94.

11. Hahn MK, Wolever TMS, Arenovich T, Teo C, Giacca A, Powell V, et al. Acute Effects of Single-Dose Olanzapine on Metabolic, Endocrine, and Inflammatory Markers in Healthy Controls. J Clin Psychopharmacol. 2013;33:740-6.

12. Albaugh VL, Singareddy R, Mauger D, Lynch CJ. A Double Blind, PlaceboControlled, Randomized Crossover Study of the Acute Metabolic Effects of Olanzapine in Healthy Volunteers. PLoS One. 2011;6(8):e22662. doi: 
10.1371/journal.pone.0022662

13. Fell MJ, Anjum N, Dickinson K, Marshall KM, Peltola LM, Vickers S, et al. The distinct effects of subchronic antipsychotic drug treatment on macronutrient selection, body weight, adiposity, and metabolism in female rats. Psychopharmacology. 2007;194:221-31.

14. Kalinichev M, Rourke C, Daniels AJ, Grizzle MK, Britt CS, Ignar DM, et al. Characterisation of olanzapine-induced weight gain and effect of aripiprazole vs olanzapine on body weight and prolactin secretion in female rats. Psychopharmacology. 2005;182:220-31.

15. Minet-Ringuet J, Even PC, Guesdon B, Tomé D, de Beaurepaire R. Effects of chronic neuroleptic treatments on nutrient selection, body weight, and body composition in the male rat under dietary self-selection. Behav Brain Res. 2005;163:204-11.

16. Victoriano M, Hermier D, Even PC, Fromentin G, Huneau J-F, Tomé D, et al. Early perturbation in feeding behaviour and energy homeostasy in olanzapine-treated rats. Psychopharmacology. 2009;206:167-76.

17. Lau SL, Muir C, Assur Y, Beach R, Tran B, Bartrop R, et al. Predicting Weight Gain in Patients Treated With Clozapine. J Clin Psychopharmacol. 2016;36:120-4.

18. Covell NH, Weissman EM, Essock SM. Weight gain with clozapine compared to first generation antipsychotic medications. Schizophr Bull. 2004;30:22940.

19. Xiang Y-T, Wang C-Y, Si T-M, Lee EH, He YL, Ungvari GS, et al. Sex Differences in Use of Psychotropic Drugs and Drug-Induced Side Effects in Schizophrenia Patients: Findings of the Research on Asia Psychotropic Prescription (REAP) Studies. Aust New Zeal J Psychiatry. 2011;45:193-8.

20. Haack S, Seeringer A, Thürmann PA, Becker T, Kirchheiner J. Sex-specific differences in side effects of psychotropic drugs: genes or gender? Pharmacogenomics. 2009;10:1511-1526.

21. Hakko H, Komulainen MT, Koponen H, Saari K, Laitinen J, Järvelin MR, et al. Are females at special risk of obesity if they become psychotic? The longitudinal Northern Finland 1966 Birth Cohort Study. Schizophr Res. 2006;84:15-9.

22. Verma S, Liew A, Subramaniam M, Poon LY. Effect of Treatment on Weight Gain and Metabolic Abnormalities in Patients with First-Episode Psychosis. Aust New Zeal J Psychiatry. 2009;43:812-7.

23. Lee E, Leung C-M, Wong E. Atypical antipsychotics and weight gain in Chinese patients: a comparison of olanzapine and risperidone. J Clin Psychiatry. 2004;65:864-6.

24. Lipkovich I, Jacobson JG, Caldwell C, Hoffmann VP, Kryzhanovskaya L, Beasley CM. Early predictors of weight gain risk during treatment with olanzapine: analysis of pooled data from 58 clinical trials. Psychopharmacol Bull. 2009;42:23-39.

25. Attux C, Quintana MI, Chaves AC. Weight gain, dyslipidemia and altered parameters for metabolic syndrome on first episode psychotic patients after six-month follow-up. Rev Bras Psiquiatr. 2007;29:346-9. 
26. Taylor JH, Jakubovski E, Gabriel D, Bloch MH. Predictors and Moderators of Antipsychotic-Related Weight Gain in the Treatment of Early-Onset Schizophrenia Spectrum Disorders Study. J Child Adolesc Psychopharmacol. 2018;28:474-84.

27. Sušilová L, Češková E, Hampel D, Sušil A7, Šimůnek J. Changes in BMI in hospitalized patients during treatment with antipsychotics, depending on gender and other factors. Int J Psychiatry Clin Pract. 2017;21:112-7.

28. Lane H-Y, Liu Y-C, Huang C-L, Chang YC, Wu PL, Lu CT, et al. Risperidonerelated weight gain: genetic and nongenetic predictors. J Clin Psychopharmacol. 2006;26:128-34.

29. Konarzewska B, Stefańska E, Wendołowicz A, Cwalina U, Golonko A, Małus A, et al. Visceral obesity in normal-weight patients suffering from chronic schizophrenia. BMC Psychiatry. 2014;14:35.

30. Sugawara N, Yasui-Furukori N, Tsuchimine S, Fujii A, Sato Y, Saito M, et al. Body composition in patients with schizophrenia: Comparison with healthy controls. Ann Gen Psychiatry. 2012;11:11.

31. Zhang Z-J, Yao Z-J, Liu W, Fang Q, Reynolds GP. Effects of antipsychotics on fat deposition and changes in leptin and insulin levels. Magnetic resonance imaging study of previously untreated people with schizophrenia. Br J Psychiatry. 2004;184:58-62.

32. Satoh M, Sakuda H, Kobayashi T, Kataoka T, Nakao F, Turale S. Comparison of the body fluid levels in healthy individuals and those with schizophrenia in Japan: using the bioelectrical impedance method. Nurs Health Sci. 2007;9:177-84.

33. Albaugh VL, Henry CR, Bello NT, Hajnal A, Lynch SL, Halle B, et al. Hormonal and metabolic effects of olanzapine and clozapine related to body weight in rodents. Obesity (Silver Spring). 2006;14:36-51.

34. Arjona A, Zhang SX, Adamson B, Wurtman RJ. An animal model of antipsychotic-induced weight gain. Behav Brain Res. 2004;152:121-7.

35. Cooper GD, Pickavance LC, Wilding JPH, Halford JC, Goudie AJ. A parametric analysis of olanzapine-induced weight gain in female rats. Psychopharmacology (Berl). 2005;181:80-9.

36. Cooper GD, Harrold JA, Halford JCG, Goudie AJ. Chronic clozapine treatment in female rats does not induce weight gain or metabolic abnormalities but enhances adiposity: Implications for animal models of antipsychoticinduced weight gain. Prog Neuro-Psychopharmacology Biol Psychiatry. 2008;32:428-36.

37. Ersland KM, Myrmel LS, Fjære E, Berge RK, Madsen L, Steen VM, et al. OneYear Treatment with Olanzapine Depot in Female Rats: Metabolic Effects. Int J Neuropsychopharmacol. 2019;22:358-69.

38. Fell MJ, Marshall KM, Williams J, Neill JC. Effects of the Atypical Antipsychotic Olanzapine on Reproductive Function and Weight Gain in Female Rats. J Psychopharmacol. 2004;18:14955.

39. Goudie AJ, Smith JA, Halford JCG. Characterization of olanzapine-induced weight gain in rats. J Psychopharmacol. 2002;16:291-6.

40. Hu Y, Young AJ, Ehli EA, Nowotny D, Davies PS, Droke EA, et al. Metformin 
and Berberine Prevent Olanzapine-Induced Weight Gain in Rats. PLoS One. 2014;9:e93310.

41. Lykkegaard K, Larsen PJ, Vrang N, Bock C, Bock T, Knudsen LB. The oncedaily human GLP-1 analog, liraglutide, reduces olanzapine-induced weight gain and glucose intolerance. Schizophr Res. 2008;103:94-103.

42. Mann S, Chintoh A, Giacca A, Fletcher P, Nobrega J, Hahn M, et al. Chronic olanzapine administration in rats: Effect of route of administration on weight, food intake and body composition. Pharmacol Biochem Behav. 2013;103:717-22.

43. Pouzet B, Mow T, Kreilgaard M, Velschow S. Chronic treatment with antipsychotics in rats as a model for antipsychotic-induced weight gain in human. Pharmacol Biochem Behav. 2003;75:133-40.

44. Skrede S, Martins L, Berge RK, Steen VM, López M, Fernø J. Olanzapine depot formulation in rat: A step forward in modelling antipsychotic-induced metabolic adverse effects. Int J Neuropsychopharmacol. 2014;17:91-104.

45. Skrede S, Fernø J, Vázquez MJ, Fjær S, Pavlin T, Lunder N, et al. Olanzapine, but not aripiprazole, weight-independently elevates serum triglycerides and activates lipogenic gene expression in female rats. Int $\mathrm{J}$ Neuropsychopharmacol. 2012;15:163-79.

46. Skrede S, González-García I, Martins L, Berge RK, Nogueiras R, TenaSempere M, et al. Lack of Ovarian Secretions Reverts the Anabolic Action of Olanzapine in Female Rats. Int J Neuropsychopharmacol. 2017;20:1005-12.

47. Ader M, Kim SP, Catalano KJ, Ionut V, Hucking K, Richey JM, et al. Metabolic dysregulation with atypical antipsychotics occurs in the absence of underlying disease: a placebo-controlled study of olanzapine and risperidone in dogs. Diabetes. 2005;54:862-71.

48. Albaugh VL, Judson JG, She P, Lang CH, Maresca KP, Joyal JL, et al. Olanzapine promotes fat accumulation in male rats by decreasing physical activity, repartitioning energy and increasing adipose tissue lipogenesis while impairing lipolysis. Mol Psychiatry. 2011;16:569-81.

49. Baptista T, Mata A, Teneud L, de Quijada M, Han HW, Hernández L. Effects of long-term administration of clozapine on body weight and food intake in rats. Pharmacol Biochem Behav. 1993;45:51-4.

50. Cooper GD, Pickavance LC, Wilding JPH, Harrold JA, Halford JC, Goudie AJ. Effects of olanzapine in male rats: enhanced adiposity in the absence of hyperphagia, weight gain or metabolic abnormalities. J Psychopharmacol. 2007;21:405-13.

51. Ferno J, Ersland KM, Duus IH, González-García I, Fossan KO, Berge RK, et al. Olanzapine depot exposure in male rats: Dose-dependent lipogenic effects without concomitant weight gain. Eur Neuropsychopharmacol. 2015;25: 923-32.

52. Minet-Ringuet J, Even PC, Lacroix M, Tomé D, de Beaurepaire R. A model for antipsychotic-induced obesity in the male rat. Psychopharmacology (Berl). 2006;187:447-54.

53. Minet-Ringuet J, Even PC, Goubern M, Tomé D, de Beaurepaire R. Long term treatment with olanzapine mixed with the food in male rats induces body 
fat deposition with no increase in body weight and no thermogenic alteration. Appetite. 2006;46:254-62.

54. Smith GC, Chaussade C, Vickers M, Jensen J, Shepherd PR. Atypical antipsychotic drugs induce derangements in glucose homeostasis by acutely increasing glucagon secretion and hepatic glucose output in the rat. Diabetologia. 2008;51:2309-17.

55. Smith GC, Vickers MH, Cognard E, Shepherd PR. Clozapine and quetiapine acutely reduce glucagon-like peptide-1 production and increase glucagon release in obese rats: implications for glucose metabolism and food choice behaviour. Schizophr Res. 2009;115:30-40.

56. Fernø J, Varela L, Skrede S, Vázquez MJ, Nogueiras R, Diéguez C, et al. Olanzapine-Induced Hyperphagia and Weight Gain Associate with Orexigenic Hypothalamic Neuropeptide Signaling without Concomitant AMPK Phosphorylation. PLoS One. 2011;6:e20571.

57. Ersland KM, Skrede S, Røst TH, Berge RK, Steen VM. Antipsychotic-induced metabolic effects in the female rat: Direct comparison between long-acting injections of risperidone and olanzapine. J Psychopharmacol. 2015;29:1280-9.

58. Kapur S, VanderSpek SC, Brownlee BA, Nobrega JN. Antipsychotic dosing in preclinical models is often unrepresentative of the clinical condition: a suggested solution based on in vivo occupancy. J Pharmacol Exp Ther. 2003;305:625-31.

59. Coccurello R, Brina D, Caprioli A, Conti R, Ghirardi O, Schepis F, et al. 30 Days of Continuous Olanzapine Infusion Determines Energy Imbalance, Glucose Intolerance, Insulin Resistance, and Dyslipidemia in Mice. J Clin Psychopharmacol. 2009;29:576-83.

60. Houseknecht KL, Robertson AS, Zavadoski W, Gibbs EM, Johnson DE, Rollema H. Acute effects of atypical antipsychotics on whole-body insulin resistance in rats: implications for adverse metabolic effects. Neuropsychopharmacology. 2007;32:289-97.

61. Townsend LK, Peppler WT, Bush ND, Wright DC. Obesity exacerbates the acute metabolic side effects of olanzapine. Psychoneuroendocrinology. 2018;88:121-8.

62. Després J-P. Body fat distribution and risk of cardiovascular disease: an update. Circulation. 2012;126:1301-13.

63. Sironi AM, Petz R, De Marchi D, Buzzigoli E, Ciociaro D, Positano V, et al. Impact of increased visceral and cardiac fat on cardiometabolic risk and disease. Diabet Med. 2012;29:622-7.

64. Gruzdeva O, Borodkina D, Uchasova E, Dyleva Y, Barbarash O. Localization of fat depots and cardiovascular risk. Lipids Health Dis. 2018;17:218.

65. Ryan MC, Flanagan S, Kinsella U, Keeling F, Thakore JH. The effects of atypical antipsychotics on visceral fat distribution in first episode, drugnaive patients with schizophrenia. Life Sci. 2004;74:1999-2008.

66. Nilsson BM, Forslund AH, Olsson RM, Hambraeus L, Wiesel FA. Differences in resting energy expenditure and body composition between patients with schizophrenia and healthy controls. Acta Psychiatr Scand. 2006;114:27-35.

67. Saarni SE, Saarni SI, Fogelholm M, Heliövaara M, Perälä J, Suvisaari J, et al. 
Body composition in psychotic disorders: a general population survey. Psychol Med. 2009;39:801-10.

68. Kraal AZ, Ward KM, Ellingrod VL. Sex Differences in Antipsychotic Related Metabolic Functioning in Schizophrenia Spectrum Disorders. Psychopharmacol Bull. 2017;47:8-21.

69. Teff KL, Rickels MR, Grudziak J, Fuller C, Nguyen HL, Rickels K. Antipsychotic-induced insulin resistance and postprandial hormonal dysregulation independent of weight gain or psychiatric disease. Diabetes. 2013;62:3232-40.

70. Sowell MO, Mukhopadhyay N, Cavazzoni P, Shankar S, Steinberg HO, Breier A, et al. Hyperglycemic Clamp Assessment of Insulin Secretory Responses in Normal Subjects Treated with Olanzapine, Risperidone, or Placebo. J Clin Endocrinol Metab. 2002;87:2918-23.

71. Sowell M, Mukhopadhyay N, Cavazzoni P, Carlson C, Mudaliar S, Chinnapongse S, et al. Evaluation of Insulin Sensitivity in Healthy Volunteers Treated with Olanzapine, Risperidone, or Placebo: A Prospective, Randomized Study Using the Two-Step Hyperinsulinemic, Euglycemic Clamp. J Clin Endocrinol Metab. 2003;88:5875-80.

72. Kopf D, Gilles M, Paslakis G, Medlin F, Lederbogen F, Lehnert H, et al. Insulin Secretion and Sensitivity after Single-Dose Amisulpride, Olanzapine or Placebo in Young Male Subjects: Double Blind, Cross-Over Glucose Clamp Study. Pharmacopsychiatry. 2012;45:223-8.

73. Sacher J, Mossaheb N, Spindelegger C, Klein N, Geiss-Granadia T, Sauermann $\mathrm{R}$, et al. Effects of olanzapine and ziprasidone on glucose tolerance in healthy volunteers. Neuropsychopharmacology. 2008;33:1633-41.

74. Vidarsdottir S, Roelfsema F, Frolich M, Pijl H. Olanzapine shifts the temporal relationship between the daily acrophase of serum prolactin and cortisol concentrations rhythm in healthy men. Psychoneuroendocrinology. 2009;34:705-12.

75. Vidarsdottir S, de Leeuw van Weenen JE, Frölich M, Roelfsema F, Romijn JA, Pijl H. Effects of olanzapine and haloperidol on the metabolic status of healthy men. J Clin Endocrinol Metab. 2010;95:118-25.

76. Boyda H, Procyshyn R, Tse L, Hawkes E, Jin CH, Pang CC, et al. Differential effects of 3 classes of antidiabetic drugs on olanzapine-induced glucose dysregulation and insulin resistance in female rats. J Psychiatry Neurosci. 2012;37:407-15.

77. Boyda HN, Procyshyn RM, Asiri Y, Wu C, Wang CK, Lo R, et al. Antidiabeticdrug combination treatment for glucose intolerance in adult female rats treated acutely with olanzapine. Prog Neuro-Psychopharmacol Biol Psychiatry. 2014;48:170-6.

78. Jassim G, Skrede S, Vázquez MJ, Wergedal H, Vik-Mo AO, Lunder N, et al. Acute effects of orexigenic antipsychotic drugs on lipid and carbohydrate metabolism in rat. Psychopharmacology. 2012;219:783-94.

79. Martins PJF, Haas M, Obici S. Central nervous system delivery of the antipsychotic olanzapine induces hepatic insulin resistance. Diabetes. 2010;59:2418-25. 
80. Wu C, Yuen J, Boyda HN, Procyshyn RM, Wang CK, Asiri YI, et al. An Evaluation of the Effects of the Novel Antipsychotic Drug Lurasidone on Glucose Tolerance and Insulin Resistance: A Comparison with Olanzapine. PLoS One. 2014;9:e107116.

81. Albaugh VL, Vary TC, Ilkayeva O, Wenner BR, Maresca KP, Joyal JL, et al. Atypical Antipsychotics Rapidly and Inappropriately Switch Peripheral Fuel Utilization to Lipids, Impairing Metabolic Flexibility in Rodents. Schizophr Bull. 2012;38:153-66.

82. Bush ND, Townsend LK, Wright DC. AICAR Prevents Acute OlanzapineInduced Disturbances in Glucose Homeostasis. J Pharmacol Exp Ther. 2018;365:526-35.

83. Castellani LN, Peppler WT, Sutton CD, , Whitfield J, Charron MJ, Wright DC. Glucagon receptor knockout mice are protected against acute olanzapineinduced hyperglycemia. Psychoneuroendocrinology. 2017;82:38-45.

84. Castellani LN, Peppler WT, Miotto PM, Bush N, Wright DC. Exercise Protects Against Olanzapine-Induced Hyperglycemia in Male C57BL/6J Mice. Sci Rep. 2018;8:772.

85. Chintoh AF, Mann SW, Lam L, Lam C, Cohn TA, Fletcher PJ, et al. Insulin Resistance and Decreased Glucose-Stimulated Insulin Secretion After Acute Olanzapine Administration. J Clin Psychopharmacol. 2008;28:494-9.

86. Chintoh AF, Mann SW, Lam L, Giacca A, Fletcher P, Nobrega J, et al. Insulin resistance and secretion in vivo: effects of different antipsychotics in an animal model. Schizophr Res. 2009;108:127-33.

87. Girault EM, Alkemade A, Foppen E, Ackermans MT, Fliers E, Kalsbeek A. Acute peripheral but not central administration of olanzapine induces hyperglycemia associated with hepatic and extra-hepatic insulin resistance. PLoS One. 2012;7:e43244.

88. Hahn MK, Chintoh A, Remington G, Teo C, Mann S, Arenovich T, et al. Effects of intracerebroventricular (ICV) olanzapine on insulin sensitivity and secretion in vivo: An animal model. Eur Neuropsychopharmacol. 2014;24:448-58.

89. Ikegami M, Ikeda H, Ohashi T, Kai M, Osada M, Kamei A, et al. OlanzapineInduced Hyperglycemia: Possible Involvement of Histaminergic, Dopaminergic and Adrenergic Functions in the Central Nervous System. Neuroendocrinology. 2013;98:224-32.

90. Ikegami $\mathrm{M}$, Ikeda $\mathrm{H}$, Ishikawa $\mathrm{Y}$, Ohsawa $\mathrm{M}$, Ohashi $\mathrm{T}$, Kai $\mathrm{M}$, et al. Olanzapine induces glucose intolerance through the activation of AMPK in the mouse hypothalamus. Eur J Pharmacol. 2013;718:376-82.

91. Ikegami M, Ikeda $\mathrm{H}$, Ohashi $\mathrm{T}$, Ohsawa $\mathrm{M}$, Ishikawa $\mathrm{Y}$, Kai $\mathrm{M}$, et al. Olanzapine increases hepatic glucose production through the activation of hypothalamic adenosine 5'-monophosphate-activated protein kinase. Diabetes, Obes Metab. 2013;15:1128-35.

92. Klingerman CM, Stipanovic ME, Hajnal A, Lynch CJ. Acute Metabolic Effects of Olanzapine Depend on Dose and Injection Site. Dose Response. 2015;13:1559325815618915.

93. Kowalchuk C, Teo C, Wilson V, Chintoh A, Lam L, Agarwal SM, et al. In male 
rats, the ability of central insulin to suppress glucose production is impaired by olanzapine, whereas glucose uptake is left intact. J Psychiatry Neurosci. 2017;42:424-31.

94. Nagata M, Nakajima M, Ishiwata Y, Takahashi Y, Takahashi H, Negishi K, et al. Mechanism Underlying Induction of Hyperglycemia in Rats by Single Administration of Olanzapine. Biol Pharm Bull. 2016;39:754-61.

95. Castellani LN, Peppler WT, Sutton CD, Whitfield J, Charron MJ, Wright DC. Glucagon receptor knockout mice are protected against acute olanzapineinduced hyperglycemia. Psychoneuroendocrinology. 2017;82:38-45.

96. Hartfield AW, Moore NA, Clifton PG. Effects of clozapine, olanzapine and haloperidol on the microstructure of ingestive behaviour in the rat. Psychopharmacology (Berl). 2003;167:115-22.

97. Cuerda C, Velasco C, Merchán-Naranjo J, García-Peris P, Arango C. The effects of second-generation antipsychotics on food intake, resting energy expenditure and physical activity. Eur J Clin Nutr. 2014;68:146-52.

98. Sentissi O, Viala A, Bourdel MC, Kaminski F, Bellisle F, Olié JP, et al. Impact of antipsychotic treatments on the motivation to eat: preliminary results in 153 schizophrenic patients. Int Clin Psychopharmacol. 2009;24:257-64.

99. Perry B, Wang Y. Appetite regulation and weight control: the role of gut hormones. Nutr Diabetes. 2012;2:e26.

100. Colley DL, Castonguay TW. Effects of sugar solutions on hypothalamic appetite regulation. Physiol Behav. 2015;139:202-9.

101. Fountaine RJ, Taylor AE, Mancuso JP, Greenway FL, Byerley LO, Smith SR, et al. Increased Food Intake and Energy Expenditure Following Administration of Olanzapine to Healthy Men. Obesity. 2010;18:1646-51.

102. Graham KA, Perkins DO, Edwards LJ, Barrier RC Jr, Lieberman JA, Harp JB. Effect of Olanzapine on Body Composition and Energy Expenditure in Adults With First-Episode Psychosis. Am J Psychiatry. 2005;162:118-23.

103. Berg KE. Comparison of energy expenditure in men and women at rest and during exercise recovery. J Sports Med Phys Fitness. 1991;31:351-6.

104. Santosa S, Khosla S, McCready LK, Jensen MD. Effects of Estrogen and Testosterone on Resting Energy Expenditure in Older Men. Obesity. 2010;18:2392-4.

105. Lord CC, Wyler SC, Wan R, Castorena CM, Ahmed N, Mathew D, et al. The atypical antipsychotic olanzapine causes weight gain by targeting serotonin receptor 2C. J Clin Invest. 2017;127:3402-6.

106. Castellani LN, Wilkin J, Abela AR, Benarroch L, Ahasan Z, Teo C, et al. Effects of acute olanzapine exposure on central insulin-mediated regulation of whole body fuel selection and feeding. Psychoneuroendocrinology. 2018;98:127-30.

107. Fischer AW, Cannon B, Nedergaard J. Optimal housing temperatures for mice to mimic the thermal environment of humans: An experimental study. Mol Metab. 2018;7:161-70.

108. Gordon CJ. The mouse thermoregulatory system: Its impact on translating biomedical data to humans. Physiol Behav. 2017;179:55-66.

109. Lizcano F, Guzmán G. Estrogen Deficiency and the Origin of Obesity during 
Menopause. Biomed Res Int. 2014;2014:757461.

110. Mauvais-Jarvis F, Clegg DJ, Hevener AL. The Role of Estrogens in Control of Energy Balance and Glucose Homeostasis. Endocr Rev. 2013;34:309-38.

111. Rettberg JR, Yao J, Brinton RD. Estrogen: A master regulator of bioenergetic systems in the brain and body. Front Neuroendocrinol. 2014;35:8-30.

112. Park S, Hong SM, Ahn SH, Kim SH. Olanzapine, not resperidone, exacerbates $\beta$-cell function and mass in ovariectomized diabetic rats and estrogen replacement reverses them. J Psychopharmacol. 2010;24:1105-14.

113. Park S, Hong SM, Ahn ILS, Kim DS, Kim SH. Estrogen Replacement Reverses Olanzapine-Induced Weight Gain and Hepatic Insulin Resistance in Ovariectomized Diabetic Rats. Neuropsychobiology. 2010;61:148-161.

114. Shimizu H, Shimomura Y, Uehara Y, Kobayashi I, Kobayashi S. Involvement of Sex Hormone in Body Weight Gain by Selective $\mathrm{D}_{2}$ Receptor Antagonist Sulpiride. Exp Clin Endocrinol Diabetes. 2009;96:25-29.

115. Fitzgerald PB, Scaffidi A, Morris MJ, de Castella AR, Kulkarni J. The relationship of changes in leptin, neuropeptide $\mathrm{Y}$ and reproductive hormones to antipsychotic induced weight gain. Hum Psychopharmacol Clin Exp. 2003;18:551-7.

116. Handgraaf S, Dusaulcy R, Visentin F, Philippe J, Gosmain Y. 17- $\beta$ Estradiol regulates proglucagon-derived peptide secretion in mouse and human aand L cells. JCI Insight. 2018. doi: 10.1172/jci.insight.98569.

117. Tiano JP, Mauvais-Jarvis F. Importance of oestrogen receptors to preserve functional $\beta$-cell mass in diabetes. Nat Rev Endocrinol. 2012;8:342-51.

118. González-Rodríguez A, Catalán R, Penadés R, Ruiz Cortés V, Torra M, Seeman MV, et al. Antipsychotic Response Worsens With Postmenopausal Duration in Women With Schizophrenia. J Clin Psychopharmacol. 2016;36:580-7.

119. Goldstein JM, Cohen LS, Horton NJ, Lee H, Andersen S, Tohen M, et al. Sex differences in clinical response to olanzapine compared with haloperidol. Psychiatry Res. 2002;110:27-37.

120. Weiss U, Marksteiner J, Kemmler G, Saria A, Aichhorn W. Effects of age and sex on olanzapine plasma concentrations. J Clin Psychopharmacol. 2005;25:570-4.

121. Regitz-Zagrosek V, Lehmkuhl E, Weickert MO. Gender differences in the metabolic syndrome and their role for cardiovascular disease. Clin Res Cardiol. 2006;95:136-47.

122. Guo C, Li Q, Tian G, Liu Y, Sun X, Yin Z, et al. Association of age at menopause and type 2 diabetes: A systematic review and dose-response meta-analysis of cohort studies. Prim Care Diabetes. 2019;13:301-9.

123. Isidori AM, Giannetta E, Greco EA, Gianfrilli D, Bonifacio V, Isidori A, et al. Effects of testosterone on body composition, bone metabolism and serum lipid profile in middle-aged men: a meta-analysis. Clin Endocrinol (Oxf). 2005;63:280-93.

124. Soldin OP, Mattison DR. Sex differences in pharmacokinetics and pharmacodynamics. Clin Pharmacokinet. 2009;48:143-57.

125. Callaghan JT, Bergstrom RF, Ptak LR, et al. Olanzapine. Clin Pharmacokinet. 1999;37:177-93. 
126. Relling M V, Lin J, Ayers GD, Evans WE. Racial and gender differences in Nacetyltransferase, xanthine oxidase, and CYP1A2* activities. Clin Pharmacol Ther. 1992;52:643-58.

127. Rasmussen BB, Brøsen K. Determination of urinary metabolites of caffeine for the assessment of cytochrome P4501A2, xanthine oxidase, and Nacetyltransferase activity in humans. Ther Drug Monit. 1996;18:254-62.

128. Hanley MJ, Abernethy DR, Greenblatt DJ. Effect of Obesity on the Pharmacokinetics of Drugs in Humans. Clin Pharmacokinet. 2010;49:71-87.

129. Maier L, Pruteanu M, Kuhn M, Zeller G2, Telzerow A, Anderson EE, et al. Extensive impact of non-antibiotic drugs on human gut bacteria. Nature. 2018;555:623-8.

130. Vrieze A, Van Nood E, Holleman F, Salojärvi J, Kootte RS, Bartelsman JF, et al. Transfer of intestinal microbiota from lean donors increases insulin sensitivity in individuals with metabolic syndrome. Gastroenterology. 2012;143:913-6.e7.

131. Küme T, Acar S, Tuhan H, Çatlı G, Anık A, Gürsoy Çalan Ö, et al. The Relationship between Serum Zonulin Level and Clinical and Laboratory Parameters of Childhood Obesity. J Clin Res Pediatr Endocrinol. 2017;9:31-38.

132. Boulangé CL, Neves AL, Chilloux J, Nicholson JK, Dumas ME. Impact of the gut microbiota on inflammation, obesity, and metabolic disease. Genome Med. 2016;8:42.

133. Stępień M, Stępień A, Wlazeł RN, Paradowski M, Banach M, Rysz J. Obesity indices and inflammatory markers in obese non-diabetic normo- and hypertensive patients: a comparative pilot study. Lipids Health Dis. 2014;13:29.

134. Bischoff SC, Barbara G, Buurman W, Ockhuizen T, Schulzke J-D, Serino M, et al. Intestinal permeability - a new target for disease prevention and therapy. BMC Gastroenterol. 2014;14:189.

135. Spiegelman BM, Flier JS. Obesity and the regulation of energy balance. Cell. 2001;104:531-43.

136. Morgan AP, Crowley JJ, Nonneman RJ, Quackenbush CR, Miller CN, Ryan A, et al. The Antipsychotic Olanzapine Interacts with the Gut Microbiome to Cause Weight Gain in Mouse. PLoS One. 2014;9:e115225.

137. Bahr SM, Weidemann BJ, Castro AN, Walsh JW, deLeon O, Burnett CM, et al. Risperidone-induced weight gain is mediated through shifts in the gut microbiome and suppression of energy expenditure. EBioMedicine. 2015;2:1725-34.

138. Bahr SM, Tyler BC, Wooldridge N, Butcher BD, Burns TL, Teesch LM, et al. Use of the second-generation antipsychotic, risperidone, and secondary weight gain are associated with an altered gut microbiota in children. Transl Psychiatry. 2015;5:e652.

139. Flowers SA, Evans SJ, Ward KM, et al. Interaction Between Atypical Antipsychotics and the Gut Microbiome in a Bipolar Disease Cohort. Pharmacother J Hum Pharmacol Drug Ther. 2017;37:261-7.

140. Cani PD, de Vos WM. Next-Generation Beneficial Microbes: The Case of Akkermansia muciniphila. Front Microbiol. 2017;8:1765. 
141. Yuan X, Zhang P, Wang Y, Liu Y, Li X, Kumar BU, et al. Changes in metabolism and microbiota after 24-week risperidone treatment in drug naïve, normal weight patients with first episode schizophrenia. Schizophr Res. 2018;201:299-306.

142. Flowers SA, Baxter NT, Ward KM, Kraal AZ, McInnis MG, Schmidt TM, et al. Effects of Atypical Antipsychotic Treatment and Resistant Starch Supplementation on Gut Microbiome Composition in a Cohort of Patients with Bipolar Disorder or Schizophrenia. Pharmacother J Hum Pharmacol Drug Ther. 2019;39:161-70.

How to cite this article:

Castellani LN, Costa-Dookhan KA, McIntyre WB, Wright DC, Flowers SA, Hahn MK, et al. Preclinical and Clinical Sex Differences in Antipsychotic-Induced Metabolic Disturbances: A Narrative Review of Adiposity and Glucose Metabolism. J Psychiatry Brain Sci. 2019;4:e190013. https://doi.org/10.20900/jpbs.20190013 